Notre Dame Law Review

Volume $89 \mid$ Issue 1

Article 5

$11-2013$

\title{
The Appointment and Removal of William J. Marbury and When an Office Vests
}

Saikrishna Bangalore Prakash

University of Virginia School of Law

Follow this and additional works at: http://scholarship.law.nd.edu/ndlr

Part of the Constitutional Law Commons, Courts Commons, Legal History, Theory and Process Commons, Politics Commons, and the President/Executive Department Commons

\section{Recommended Citation}

89 Notre Dame L. Rev. 199

This Article is brought to you for free and open access by NDLScholarship. It has been accepted for inclusion in Notre Dame Law Review by an authorized administrator of NDLScholarship. For more information, please contact lawdr@nd.edu. 


\title{
THE APPOINTMENT AND REMOVAL OF WILLIAM J. MARBURY AND WHEN AN OFFICE VESTS
}

\author{
Saikrishna Bangalore Prakash*
}

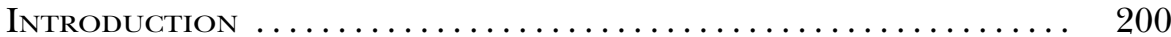

I. A Strategy of Removal and Reappointment . . . . . . . . 206

II. Five Theories of When an Appointment Vests ......... 216

A. By the Advice and Consent of the Senate ............ 217

B. After the Senate Consents, But Before Commissioning ..... 220

C. Commissioning......................... 222

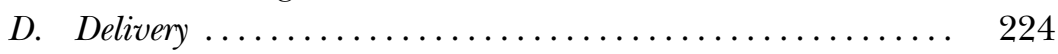

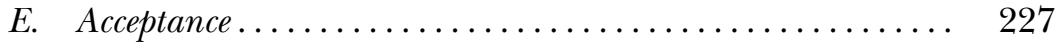

III. The Making of Appointments under the Constitution . 230

A. The Discretionary Theory of Appointment........... 231

B. The Discretionary Theory Applied to Other Provisions ..... 232

C. Restrictions on the Rule of Appointer Discretion ......... 236

D. The Functions of Commissions ................ 241

E. Congress, the Senate, and the Vesting of Appointments .... 244

F. Reconsidering the Theories of Appointment........... 247

IV. The Marbury Appointment Revisited .................. 248

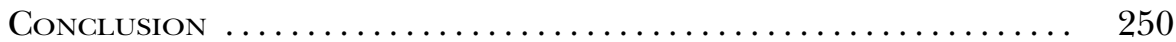

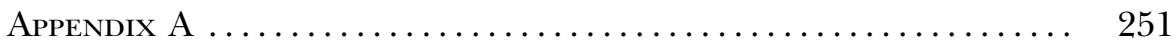

(C) 2013 Saikrishna Bangalore Prakash. Individuals and nonprofit institutions may reproduce and distribute copies of this Article in any format at or below cost, for educational purposes, so long as each copy identifies the author, provides a citation to the Notre Dame Law Review, and includes this provision in the copyright notice.

* James Monroe Distinguished Professor of Law, Horace W. Goldsmith Research Professor, University of Virginia School of Law. Thanks to Scott Baker, Kevin Collins, Deborah Dinner, Aziz Huq, John Inazu, Kurt Lash, David Law, Tom Ginsburg, Ronald Levine, Greg Magarian, David Strauss, Suja Thomas, Laura Weinreb, Ted White, and participants in the Chicago Law School Works-in-Progress Workshop, the Washington University Faculty Workshop, and the University of Illinois Constitutional Colloquium for comments. Thanks also to John Harrison for helpful conversations. Finally, thanks to the reference librarians at the University of Virginia for research support, to Andrew Bentz, Simon Cataldo, Rachel Kincaid, Alexander Krueger-Wyman, W. Andrew Lanius, Seth Meyer, and Archith Ramkumar for research assistance and comments, and to the Virginia Law School for summer research support. 


\section{AbSTRACT}

Scholars have ignored the most important question in one of the most famous constitutional law cases, obscuring the machinations that spawned the dispute. This Article sheds light on the events that precipitated Marbury v. Madison and also explains when an appointment vests. Thomas Jefferson famously refused to deliver a commission to William J. Marbury, causing the latter to seek a writ of mandamus from the Supreme Court. The received wisdom supposes that Jefferson's refusal rested on the grounds that Marbury had not been appointed a justice of the peace precisely because he never had received a commission. In fact, Jefferson's delivery argument was a post-hoc rationalization, having nothing to do with his actions in March of 1801. John Adams's midnight appointments incensed Jefferson, leading the new President to treat all of the justice of the peace appointments as nullities. To Jefferson, the failure to deliver commissions to some of those appointees mattered not a whit. What seems to have been far more significant is his sense that the justices of the peace served at his pleasure. Acting on this belief, he simultaneously removed them all and recessappointed most of them, save for more than a dozen, including William J. Marbury. This Article also addresses whether William J. Marbury and the other midnight appointees who never received their commissions were nonetheless appointed, considering five theories of when an appointment vests: when the Senate consents; after consent but before commissioning; when commissioning occurs; with the delivery of a commission; and with acceptance of the office. In the course of considering these theories, the Article discloses the surprising fact that Thomas Jefferson, as Secretary of State, endorsed the second theory, namely that appointments vest before the act of commissioning. Moreover, well before Marbury v. Madison, the Adams Administration likewise concluded that appointments could vest prior to any commission being issued or delivered. Despite this convergence, the Article contends that none of the five theories is correct because each reads the Constitution as enshrining a single answer regarding when an appointment vests. There is no single answer. Rather an appointment vests whenever the President determines that it shall. The Constitution grants power to the President to appoint, never precisely specifying when or how an appointment vests. By not specifying when or how appointment is made, the Constitution leaves it to the President to decide the manner in which he appoints. This conclusion derives from a general principle of constitutional law: When the Constitution grants power to an entity but does not specify the precise means by which it will be exercised, the grantee may decide the means of exercising it.

\section{INTRODUCTION}

Scholars have dissected Marbury $v$. Madison ad nauseum. They have trained their energies on the broader battle between the Republicans and Federalists, what mistakes Chief Justice John Marshall made in his opinion, whether leaving the jurisdictional issue for last was deviously brilliant, and whether he concocted judicial review. ${ }^{1}$

1 The books and articles on Marbury are almost innumerable. Among the best are Alexander Bickel, The Least Dangerous Branch (1962); Robert lowry Clinton, Marbury v. Madison and Judicial Review (1989); Donald O. Dewey, Marshall versus Jeffer- 
Missing from these works is any sustained analysis of the question foremost in the minds of William Marbury and John Marshall: Had John Adams appointed Marbury prior to leaving office? ${ }^{2}$ If he had, Jefferson and Secretary of State Madison arguably violated Marbury's rights by denying him a commission, for one of the President's Article II duties is to "commission all Officers of the United States."3 Or at least that is the prism through which the plaintiffs saw the dispute. After all, they sought copies of their commission, documents that confirmed their previous appointments. ${ }^{4}$ Certainly that

son 130 (1970); Charles F. Hobson, The Great Chief Justice: John Marshall And the Rule Of Law 47-71 (1996); Leonard W. Levy, Original Intent And the Framers' Constitution 75-88 (1988); Sylvia Snowiss, Judicial Review and the Law of the Constitution (1990); Dean Alfange Jr., Marbury v. Madison and Original Understanding of Judicial Review: In Defense of Traditional Wisdom, 1993 Sup. Cт. Rev. 329, 329-33 (1993); William W. Van Alstyne, A Critical Guide to Marbury v. Madison, 1969 Duke L.J. 1; Akhil Reed Amar, Marbury, Section 13, and the Original Jurisdiction of the Supreme Court, 56 U. CHI. L. Rev. 443 (1989); David F. Forte, Marbury's Travail: Federalist Politics and William Marbury's Appointment as Justice of the Peace, 45 Cath. U. L. Rev. 349 (1996); Michael J. Klarman, How Great Were The "Great" Marshall Court Decisions?, 87 VA. L. Rev. 1111, 1113-44 (2001); Michael W. McConnell, The Story of Marbury v. Madison: Making Defeat Look Like Victory, in Constitutional Law Stories 13 (Michael Dorf ed., 1994); James M. O’Fallon, Marbury, 44 Stan. L. Rev. 219 (1992); Jack N. Rakove, The Origins of Judicial Review: A Plea for New Contexts, 49 Stan. L. Rev. 1031 (1997); Alan F. Westin, Introduction to Charles A. Beard, The Supreme Court And the Constitution (Prentice-Hall 1962) (1912).

For a discussion of Marbury within the sweep of American legal history, see 1 G. Edward White, Law in American History: From the Colonial Years to the Civil War 210-20 (2012).

2 When scholars have considered the appointment question, they usually say no more than that Marshall's claims about when an appointment vests were not obviously right. See, e.g., Van Alystne, supra note 1, at 10 (noting that Marshall's conclusion has been "substantially modified" by the Supreme Court); Michael Stokes Paulsen, Marbury's Wrongness, 20 Const. Comment. 343, 345, 348 (2003) (arguing that Marshall was wrong in holding that Marbury's appointment had vested). In fairness, both examine numerous legal issues raised by the opinion, making it impossible to examine any one in depth.

Perhaps because scholars have ignored the question of when an appointment vests, courts that discuss the issue invariably treat Marbury as dispositive, despite the fact that its discussion is clearly dicta. These tendencies were not lost on Jefferson. See Letter from Thomas Jefferson to William Johnson (June 12, 1823), in 12 The Works of ThOMAs Jefrerson 256 n.I (Paul L. Ford ed., 1905). Courts often cite Marbury for the proposition that there must be a time when an appointment is complete, a statement that no one can dispute and one that does not specify when or how an appointment is made complete. See, e.g., Nat'l Treasury Emps. Union v. Reagan, 663 F.2d 239, 242 (D.C. Cir. 1981) ("For more than one hundred and seventy-five years, the rule as to when an appointment takes place has been clear: "when the last act to be done by the [appointing authority] was performed ....'” (quoting Marbury v. Madison, 5 U.S. (1 Cranch) 137, 156 (1803)) (alteration in original)); Speed v. United States, 97 Fed. Cl. 58, 70 (2011) ("A federal employee is appointed to a position 'when the last act to be done by the [appointing authority] [i]s performed." (quoting Nat'l Treasury Emps. Union, 663 F.2d at 242) (alteration in original)).

3 U.S. Const. art. II, $§ 3$.

4 See McConnell, supra note 1, at 20 (noting that the plaintiffs' sought a writ of mandamus to compel Madison to handover copies of their commissions). 
is the way the Chief Justice must have seen the case. Why else discuss this issue before ultimately deciding that the Court lacked jurisdiction? In particular, why would the Chief Justice go on at great length, insisting that the commission was evidence that Adams had already appointed Marbury; that if the commission was the appointment, the President's signature vested the office; that if the signature was insufficient, that sealing the commission made the officer; and that if delivery was required, delivery to the Secretary of State was sufficient? Jefferson surely understood the question's import, for Marshall had branded the President a scofflaw. ${ }^{5}$ Marshall's claims "stuck in Jefferson's craw for the rest of his life." 6

When an appointment vests matters. For the appointee, it marks the point when she may function in office and draw a salary. It is especially important when the office has a durable tenure, such as good behavior tenure. $^{7}$ The question of when an appointment vests matters to the President, too. Even as to officers serving at pleasure, removal can be risky. The list of chief executives condemned, impeached, or challenged in court for removals includes George Washington, ${ }^{8}$ Andrew Jackson, ${ }^{9}$ Andrew Johnson, ${ }^{10}$ Franklin Roosevelt, ${ }^{11}$ and George W. Bush. ${ }^{12}$ Finally, when an office vests matters to the public because it marks when a private citizen can act as an officialprosecute, create rules, or adjudicate cases.

When an appointment vests also matters because it is part of a broader question of when events of constitutional significance occur. For instance, when does a pardon vest? Does it vest when the President signs the pardon, upon notification, upon delivery, or some other time? Or consider an officer's removal. Is the officer ousted when the President decides as much, when the public is advised, or when the officer receives notice? The answer

5 G. Edward White's discussion best captures the contemporary significance of the appointment question. See White, supra note 1, at 216.

6 Louis H. Pollak, Marbury v. Madison: What Did John Marshall Decide and Why?, 148 Proc. Am. Phil. Soc'y 1, 5 n.10 (2004).

7 U.S. Const. art. III, $\S 1$ (federal judges hold office during "good Behaviour"). For an explication of this tenure, see Saikrishna Prakash \& Steven D. Smith, How to Remove a Federal Judge, 116 YaLE L.J. 72 (2006).

8 See James Monroe, A View of the Conduct of the Executive in Conduct of the Foreign Affairs of the United States, Connected with the Mission to the French Republic, During the Years 1794-1796 (Kessinger Publ'g, LLC 2007) (1798) (criticizing Washington for removing him from office of Minister Plenipotentiary to France).

9 The Senate censured Andrew Jackson for his removal of the Treasury Secretary. See Robert V. Remini, Andrew Jackson and the Bank War 137-38 (1967).

10 See generally Michael Les Benedict, The Impeachment and Trial of Andrew JohnSON (1973) (discussing Andrew Johnson's impeachment); David O. STEwart, Impeached: The Trial of President Andrew Johnson and the Fight for Lincoln's Legacy (2009) (same).

11 See, e.g., Humphrey's Ex'r v. United States, 295 U.S. 602, 630-31 (1935) (upholding a challenge to Roosevelt's removal of a commissioner of the Federal Trade Commission).

12 See Adam Zagorin, Why Were These U.S. Attorneys Fired?, Time (Mar. 7, 2007), http:// content.time.com/time/nation/article/0,8599,1597085,00.html (discussing the allegedly political firings of eight federal prosecutors and ensuing public outcry). 
to when an appointment vests might shed light on these related issues of constitutional timing.

The failure of scholars to consider the appointment question also has left the true story of William Marbury's appointment buried. First, a glimpse of the untold story: upon assuming office in 1801, President Jefferson said he would treat all of the midnight justice of the peace appointments as if they were nullities. ${ }^{13}$ This stance meant that Jefferson cared little about whether the appointees had received commissions. ${ }^{14}$ Underscoring his view that the midnight appointments were to be treated as nullities, Jefferson appointed some of these appointees to the identical office, ${ }^{15}$ an action clearly signifying that they were not otherwise in office except by virtue of his appointment.

Only in 1807 , years later, did he harp on the failure to deliver certain commissions. ${ }^{16}$ Given his apparent failure to espouse the delivery theory in 1801, Jefferson's belated claim that John Adams had not appointed Marbury because the latter had received no commission was a post hoc justification. Somewhat ironically, our hyperfocus on the Marbury opinion, with its emphasis on the plaintiffs' demands for commissions, has left hidden the story of Jefferson's nullification strategy and his initial view that the commissions and the appointments were beside the point. ${ }^{17}$

If Jefferson lacked a delivery theory of appointment in 1801, what justified his treating all of the midnight appointments as nullities, as if they had never been made? While he was never crystal clear, it nonetheless seems reasonably certain that President Jefferson acted on the belief that he could remove the justices of the peace. He noted that most of the midnight appointees served at his pleasure. ${ }^{18}$ As to these non-Article III appointees, Jefferson believed that he should treat them as nullities because he thought it utterly outrageous that Adams had appointed them during the twenty-first hour of the last day of his Presidency. ${ }^{19}$ Somewhat ironically, the means by which he removed all the justices of the peace was a global commission, one that recess-appointed some of the non-Article III midnight appointees. The implication was that all justices of the peace had been terminated, with only some given new (and shorter) terms of office. ${ }^{20}$

The dearth of scholarly inquiry also has left concealed a good deal of historical evidence on an issue Chief Justice Marshall struggled with in Marbury: the question of when an appointment vests. Prior to Marbury, it was common to consider an appointment complete even when no commission

\footnotetext{
13 See infra text accompanying notes $64-69$.

14 See infra text accompanying note 96.

15 See infra text accompanying notes 57-58.

16 See infra text accompanying notes 95.

17 See infra text accompanying notes 96.

18 See Circular Letter from Thomas Jefferson to Midnight Appointees (Mar. 4, 1801), in 33 The Papers of Thomas Jefferson 172-73 (Barbara R. Oberg \& J. Jefferson Looney eds., 2005).

19 See infra text accompanying notes 101.

20 See infra text accompanying notes 100.
} 
had been issued. Commissions were hardly irrelevant; they were good and perhaps conclusive evidence of appointment. But appointments could and did vest independent of the signing, sealing, or delivery of commissions.

Evidence for this proposition comes from the practices of Jefferson's predecessors. Both George Washington and John Adams appointed to office without first issuing a commission. Moreover, in 1799, Adams and his cabinet concluded that the President had appointed officers to a court martial even though no one had signed, sealed, or delivered commissions. ${ }^{21}$

Persuasive evidence favoring some aspects of Marshall's opinion in Marbury also comes from an improbable source: Thomas Jefferson. As Secretary of State, Jefferson opined to George Washington that appointment had to precede commissioning, meaning that commission delivery was unnecessary for an appointment to vest. ${ }^{22}$ Moreover, the first Secretary of State issued commissions to individuals already appointed to office. ${ }^{23}$ Later, as President, Jefferson signed commissions that purported to appoint via the commission itself and not upon delivery. ${ }^{24}$ He even sent letters to individuals notifying them that he had appointed them even before they had their commission in hand. ${ }^{25}$ Prior to the Court issuing Marbury, he recess-appointed some of the justices of the peace that John Adams previously had appointed using language indicating that their appointment had preceded delivery of the global commission. ${ }^{26}$ Finally, around the time he first criticized Marbury, he issued commissions that purported to appoint via the signing of the commissions, without regard to delivery. ${ }^{27}$

This mass of evidence indicates that in 1807 and thereafter, Jefferson was wrong to insist that commission delivery was crucial for an appointment to vest. To the contrary, early practice proves that John Marshall was right that neither delivery of a commission nor acceptance of office was absolutely necessary to appoint to office.

Yet the Great Chief Justice was mistaken too. He wrongly insisted that delivery of a commission to the appointee and acceptance of the office were irrelevant because in both cases the President had already made the appointment. The better view is that because the Constitution does not specify when or how an appointment vests, it leaves these matters to the appointer to

21 See infra text accompanying notes 114-18.

22 See Thomas Jefferson, Opinion on the Powers of the Senate Respecting Diplomatic Appointments (Apr. 24, 1790), in 16 The PAPers of Thomas Jefferson, supra note 18, at 379.

23 See infra text accompanying notes 135-36.

24 See Commission to the Office of Secretary of State (Mar. 5, 1801), in 1 The PAPERS of James Madison 2 (Robert J. Brugger et al. eds., 1986).

25 See Letter from Thomas Jefferson to William C. Claiborne (July 13, 1801), in 34 THE Papers of Thomas JefFerson, supra note 18, at 560.

26 See Charles S. Bundy, A History of the Office of the Justice of the Peace of the District of Columbia, 5 Records of the Columbia Historical Soc'y 259, 266 (1902).

27 See 1 Elliott Coues, History of the Expedition Under the Command of Lewis and Clark, at lxxiii (Courier Dover Publications 1979) (1893) (commission providing that it appointed William Clark). 
decide. This discretionary theory posits that the Constitution cedes flexibility to appointers, permitting them to vest offices in a number of ways. ${ }^{28}$

This conclusion derives from a general principle of constitutional law: when the Constitution grants power to an entity but does not specify how and when the power must be exercised, the entity empowered may decide how and when to exercise that power. For instance, Congress may decide whether to use English, Spanish, or both, when it makes laws, for the Constitution never specifies a particular language for federal statutes. The federal courts may decide whether to issue oral or written opinions because the Constitution does not require one or the other. And the President may decide how to convey his veto objections to Congress, whether in person or via messenger, because the Constitution never fixes that detail.

Because the Constitution is best read as never dictating how or when an appointment vests, the President may decide those details with respect to his appointments. He might choose to have appointments automatically vest upon the Senate's consent. He might elect to have an appointment vest as soon as a commission is signed, sealed, or delivered. Or the President might make appointments vest only upon acceptance of the office. Hence, Marshall and Jefferson were mistaken because each definitively rejected some methods when, in fact, the Constitution leaves it to the appointer to decide how and when her appointments will vest.

To be clear, the claim is not that whenever the Constitution grants a power to a branch (e.g., commerce power or the authority as Commander in Chief), that branch is empowered to determine, authoritatively, the scope of its power. Though each branch must judge for itself what powers the Constitution cedes, it hardly follows that those judgments are conclusive or impervious to review in the other branches. Marbury $v$. Madison proves as much. Instead, the claim is that when the Constitution does not specify how a branch must exercise one of its powers, it implicitly delegates to that branch the ability to determine the means of exercising that power.

Part I tells the story of Marbury's appointment, why it incensed Jefferson, and what he did about it. Jefferson was outraged because a lame duck had foisted partisans on him. As a balm to his anger, Jefferson treated Adams's midnight appointments as nullities, without regard to whether commissions were delivered, on the theory that all of the non-Article III appointees served at his pleasure. In essence, Jefferson removed the midnight appointees. Only later, years after Marbury was issued, did Jefferson claim that delivery of a commission was essential to appointing.

Part II considers five theories of appointment bandied about in the late eighteenth and early nineteenth centuries. Some thought that the Senate's consent automatically made an appointment, with no further presidential action necessary. Others believed that an appointment vested after the Sen-

28 This Article's claims do not rest on a functional argument about how best to allocate interpretive responsibility for resolving supposed constitutional ambiguities. Rather, as noted in the text, I argue that the Constitution is best read as delegating the mechanics and timing of appointments to those who appoint. 
ate's consent and before the issuance of a commission. A third school claimed that the commission made the appointment, suggesting that signing the commission vested the office. Another group, consisting of Jefferson's partisans, claimed that without commission delivery, no appointment had been made. Finally, in Marbury, Marshall considered whether acceptance of an office completed the appointment.

Part III argues that, subject to limitations, the President may decide when an appointment vests. Because the Constitution does not specify when an appointment is made, it leaves the details to the appointer. When the President appoints, he not only can choose from among the possibilities discussed in Part II, he also can adopt other triggers, such as deciding that appointments vest upon a certain date or upon the retirement of existing officers. The point is that the Constitution does not adopt a one-size-fits-all approach to the vesting of offices. Using this framework, Part III addresses similar questions, such as when a pardon vests. Finally it considers constraints on the President's power to decide when an appointment vests and whether Congress may regulate the means of appointing.

Part IV reconsiders whether, in light of the discretionary theory, John Adams appointed William Marbury. It turns out that there is powerful (albeit indirect) evidence on this point.

\section{A Strategy of Removal and Reappointment}

Some of this story is familiar, while the rest is unknown or misunderstood. It begins not with the infamous Judiciary Act of $1801,{ }^{29}$ but with the (mostly) forgotten Organic Act of 1801 and its creation of officers for the District of Columbia. ${ }^{30}$ Our focus is on the Organic Act's grant of authority to the President to appoint as many justices of the peace ${ }^{31}$ as he deemed necessary. Each justice would have a five-year term. ${ }^{32}$

John Adams signed the Act on February 27, 1801,33 ten days after the House had elected Thomas Jefferson and a week before the latter's inauguration on March 4th. Adams waited until March 2nd to nominate forty-two justices. ${ }^{34}$ The next day, the last day of the lame duck session, the Federalist Senate confirmed them. ${ }^{35}$ That same day, Adams signed all of the commis-

29 Judiciary Act of 1801, ch. 4, 2 Stat. 89 (repealed 1802).

30 Act of Feb. 27, 1801, ch. 15, 2 Stat. 103.

31 Justices of the peace had judicial, legislative, and executive powers and were the "primary political force in the community." Forte, supra note 1, at 354 . They arrested, arraigned, and generally preserved a community's peace and morals. Id.; see also 1 THE Law-Dictionary: Explaining the Rise, Progress, and Present State of the British Law (Thomas Edlyne Tomlins ed., 1820) (entry for Justice of the Peace) (describing power to conserve peace, apprehend criminals, and try them).

32 Act of Feb. 27, 1801, ch. 15, § 11, 2 Stat. 103, 107.

33 Id.

34 1 Journal of the Executive Proceedings of the Senate of the United States of AMERICA 388 (1828).

$35 \mathrm{Id}$. at 389. 
sions and forwarded them to John Marshall, Secretary of State, so that the latter could affix the seal of the United States. ${ }^{36}$ After sealing the commissions, John Marshall asked his brother, James, to deliver them. ${ }^{37}$ But some went undelivered, supposedly because there were too many. ${ }^{38}$ John Marshall might have had someone deliver them the next day, as he remained Secretary of State a day into the Jefferson Presidency. ${ }^{39}$ But John Marshall did nothing to see them delivered. ${ }^{40}$

Much later, Jefferson claimed that upon entering the State Department for the first time, he came across the commissions and ordered that they remain unsent. ${ }^{41}$ Some have suggested that he ordered them burnt, ${ }^{42}$ with one contemporary account claiming that they were discarded along with the office's refuse. ${ }^{43}$

The midnight appointments rankled Jefferson. He believed that the lame duck ought to have appointed no one. Writing to Abigail Adams in 1804, he said that the only actions that her husband had taken that "ever gave [him] a moment's personal displeasure" 44 were his "last appointments to office." 45 Jefferson complained that those appointments "laid me under the embarrassment of acting through men whose views were to defeat mine, or to encounter the odium of putting others in their places." 46

At his inaugural address, Jefferson bit his tongue, perhaps because he was unaware of what transpired the night before. "We are all republicans: we

36 See James F. Simon, What Kind of Nation?: Thomas Jefferson, John Marshall, and the Epic Struggle to Create a United States 173-74 (2002).

$37 \quad I d$. at 174.

$38 I d$. John Marshall's letter to his brother suggests that James Marshall was not entirely to blame for the non-delivery. John Marshall explained:

I did not send out the commissions because I apprehended such as were for a fixd

[sic] time to be completed when signd [sic] and seald [sic] \& such as depended on the will of the President might at any time be revokd [sic] . . . . I should however have sent out the commissions ...."

Letter from John Marshall to James M. Marshall (Mar. 18, 1801), in 6 The PAPERs of JohN Marshall 90 (Charles F. Hobson et al. eds., 1990). Here, John Marshall speaks as if the failing was his. It also seems as if John Marshall decided that commissions did not need to be delivered, suggesting that the difficulty in delivering them was not so consequential, at least in his mind.

39 See R. Kent Newmyer, John Marshall and the Heroic Age of the Supreme Court 160 (2001).

$40 \quad I d$.

41 See Letter from Thomas Jefferson to William Johnson, supra note 2, at $256 \mathrm{n} .1$ (saying that he "forbade the[ ] delivery" of commissions found in the State Department).

42 See Leonard W. Levy, Seasoned Judgments: The American Constitution, Rights, AND History 245 (1995).

43 Extract of a Letter from a Member of Congress to his friend in this City, Am. Citizen \& Gen. Advertiser (Dec. 28, 1801) [hereinafter Letter from a Member of Congress].

44 Letter from Thomas Jefferson to Abigail Adams (June 13, 1804), in 1 The AdamsJefFerson Letters 269, 271 (Lester J. Cappon ed., 1959).

$45 \quad I d$.

$46 I d$. at 270. 
are all federalists, ${ }^{47}$ he said. The amicable tone hinted that he would retain many Federalists in office. John Marshall, who administered the oath, said the address was "well judged and conciliatory." 48

Yet the reality was that the new President faced intense pressure to replace the "monarchists" (Federalists) with suitable Republicans. ${ }^{49}$ How far to go was the only question. As Jefferson noted, no one thought that all holdovers should remain, no one supposed that all should be ousted, and no one agreed how many ought to be dismissed. ${ }^{50}$ What was clear is that if he ousted a sizable figure, Federalists would cry that he had dismissed dutiful officials to slake a thirst for the spoils of victory. ${ }^{51}$

Jefferson sought to minimize the number of apparent removals in order to lessen the expected "odium." 52 One clever method was to treat the midnight appointees as a sui generis category, one where the concept of removal might seem irrelevant. Jefferson adopted this strategy. At some point in his early days in office, Jefferson drafted a letter to be sent to midnight appointees. He observed that President Adams "not long before his retirement . . . made several appointments to civil offices holden during the will of the President."53 He further stated that the "present President deems it proper that those appointments should be a subject of reconsideration \& further enquiry." 54 Because he desired people who would execute his views, he declared: "you will therefore be pleased to consider the appointment you

47 Thomas Jefferson, Inaugural Address (Mar. 1, 1801), in 33 The Papers of Thomas JEFFERSON, supra note 18, at 149.

48 Letter from John Marshall to Charles Pinckney (Mar. 4, 1801), in Richard J. Hooker, John Marshall on the Judiciary, the Republicans, and Jefferson, March 4, 1801, 53 Aм. Hist. Rev. 518, 519-20 (1948).

49 See Carl Russel Fish, Civil Service and Patronage 29-31 (1904) (describing the pressure). One contemporary editorial complained that if there were not more removals of Federalists, "for what, in the name of God, have we [Republicans] been contending?" Note, in 34 The Papers of Thomas Jefferson, supra note 18, at 309, 310.

50 See Letter from Thomas Jefferson to William Branch Giles (Mar. 23, 1801), in 33 The Papers of Thomas Jefferson, supra note 18, at 413.

51 See Pollak, supra note 6 , at 8-10.

52 Letter from Thomas Jefferson to Pierpont Edwards (July 21, 1801), in 34 THE Papers of Thomas Jefferson, supra note 18, at 606. Carl Prince describes the tactics that Jefferson used to minimize the appearance of removals. Carl E. Prince, The Passing of the Aristocracy: Jefferson's Removal of the Federalists, 1801-1805, 57 J. Ам. Hist. 563, 566-67 (1970) (describing Jefferson's schemes as including failing to announce some removals, coercing resignations from some officeholders, and disestablishing offices).

53 Circular Letter from Thomas Jefferson to Midnight Appointees, supra note 18, at 172-73. Jefferson evidently believed that the justices of the peace were removable even as he took pains to claim that he was not removing them.

For a discussion of the President's power to remove, see Saikrishna Prakash, Removal and Tenure in Office, 92 VA. L. REv. 1779, 1815-32 (2006). For a discussion of the congressional decision that read the Constitution as conferring a removal power, see Saikrishna Prakash, New Light on the Decision of 1789, 91 Cornell L. Rev. 1021, 1067-73 (2006).

54 Circular Letter from Thomas Jefferson to Midnight Appointees, supra note 18, at 173. The editors of the Jefferson Papers surmise that the letter was sent, but cannot determine the actual addressees. Id. 
have received as if never made, of which this early notice is given to prevent any derangement which that appointment might produce." 55 If such letters were delivered, one doubts that they pleased the recipients.

We do know that Jefferson had his staff determine which commissions the previous administration delivered and which remained undelivered. ${ }^{56}$ We also know that on March 15, 1801, less than two weeks after taking office, Jefferson recess-appointed thirty justices of the peace for the District of Columbia. ${ }^{57}$ Twenty-four of these had been on Adams's list of appointees, with six new men. ${ }^{58}$ That meant that eighteen men that John Adams had sought to appoint as justices of the peace were omitted from Jefferson's recess appointee list.

Judging by lists that the Jefferson Administration compiled, everyone who had received a justice of the peace commission signed by Adams also received a new recess appointment. ${ }^{59}$ On the one hand, perhaps this was a coincidence. After all, only a half dozen fit into the category. Jefferson may have decided that he should appoint these individuals without regard to whether they had a commission from Adams. On the other hand, perhaps this pattern suggests that Jefferson believed that those who received their commissions had been appointed. Maybe he understood the litigation risk of denying them their jobs, and so he decided to appoint them himself.

Yet if Jefferson supposed that those who received their commissions were securely in office, he should not have granted new recess appointments to those who had received their commissions. After all, if he believed that commission delivery vested the appointments, those who had received commissions from Adams did not need new ones, especially ones that purported to reduce their term to the end of the next session of the Senate. Relatedly, there would have been no need to re-nominate them a year later, as Jefferson did. ${ }^{60}$ Again, at the time of Jefferson's nomination of these justices of the

55 Id:; see also Nathan Schachner, Thomas Jefferson, A Biography 670-71 (1957) (detailing Jefferson's approach to dealing with the midnight appointees). But as late as March 24, 1801, Jefferson boasted that he would ignore the appointments and not even notify the appointees that he considered their appointments nullities. See Letter from Thomas Jefferson to Benjamin Rush (Mar. 24, 1801), in 33 The Papers of Thomas Jefrerson, supra note 18 , at $436-37$.

56 See Thomas Jefferson, To the Senate: Interim Appointments, I. Tables of Justices of the Peace for the District of Columbia [before Mar. 16, 1801] (Jan. 6, 1802), in 36 THE Papers of Thomas Jefferson, supra note 18, at 314 [hereinafter Tables of Justices of the Peace] (table listing commissions, delivered and undelivered).

57 Thomas Jefferson, To the Senate: Interim Appointments, II. Memorandum on Justices of the Peace for the District of Columbia [on or before Mar. 16, 1801] (Jan. 6, 1802), in 36 The Papers of Thomas Jefferson, supra note 18, at 316 [hereinafter Memorandum on Justices of the Peace].

$58 I d$.

59 Compare Tables of Justices of the Peace, supra note 56, with Memorandum on Justices of the Peace, supra note 57.

60 See Tables of Justices of the Peace, supra note 56; see also Letter from Thomas Jefferson to the Senate (Jan. 6, 1802), in 36 The Papers of Thomas Jefferson, supra note 18, at 331-36. 
peace in 1802, they already had appointments with about four years left in office, at least under the theory that delivery of the commissions had made the appointment complete. In his message to the Senate, which gave notice of his recess appointments and advanced a reconstituted slate of justices, Jefferson ignored all the legal questions. ${ }^{61}$ He tersely noted that John Adams had nominated many of the same people in 1801 and that Adams had nominated too many justices of the peace. ${ }^{62}$ He cagily said nothing about whether Adams had successfully appointed any of those individuals as justices of the peace. ${ }^{63}$

Why did Jefferson recess-appoint those who had received their commissions? He had resolved to treat all the midnight appointments as nullities. In a half dozen or so letters written to Republicans and Federalists, Jefferson laid out his views: "[A]ll appointments to civil offices during pleasure, made after the event of the election," Jefferson wrote, " . . . are considered as nullities. I do not view the persons appointed as even candidates for the office, but make others without noticing or notifying them." 64 This last comment contained more than a bit of bluster because, as noted, Jefferson appointed the majority of Adams's midnight justices. In other letters, he emphasized the travesty's timing: "[A]ppointments" that Adams made as late as "9. aclock of the night at 12 . aclock of which he was to go out of office," 65 were an "outrage on decency," 66 making it appropriate to treat them as "nullities." 67

61 Letter from Thomas Jefferson to the Senate, supra note 60.

$62 I d$. at 336.

63 He treated other last-minute appointments slightly differently, but no less cagily. In his private notes, Jefferson had identified some of his new appointments as replacements for "midnight appointment[s]". See List of Appointments and Removals (ca. Mar. 5, 1801 -May 14, 1802), in 33 The Papers of Thomas Jefferson, supra note 18, at 674 (commenting on the replacement of Thomas Duncan, Hugh Barclay, etc). This conceded that these men had been appointed and that he was removing and replacing them. Indeed, in some of his notes, he claimed that some of the midnight appointees were being removed "on the principle of giving some participation in office to republicans." List of Appointments and Removals (after May 10, 1803), in 33 The PAPers of Thomas JefFerson, supra note 18, at 670-72 (listing "Edwd St. Loe Livermore" as so removed). In his notes from a cabinet meeting early in his administration, Jefferson similarly mentioned that he was removing Livermore and that Barclay, a "new appt" was being replaced. Notes on a Cabinet Meeting (Mar. 8, 1801), in 33 The Papers of Thomas Jefferson, supra note 18, at 219. But in his 1802 Senate message listing his appointments and removals, Jefferson conspicuously said that these individuals had been nominated, "but not appointed." See Letter from Thomas Jefferson to the Senate, supra note 60, at 333-34 (listing about twenty officials as nominated but not appointed, including Duncan, Barclay, and Livermore). It seems clear that Jefferson sought to obscure these removals by publicly asserting that Adams had never appointed the gentlemen even as he privately acknowledged that Adams had appointed them.

64 Letter from Thomas Jefferson to William Branch Giles, supra note 50, at 413-14 (emphasis added).

65 Letter from Thomas Jefferson to Benjamin Rush, supra note 55, at 437.

66 Letter from Thomas Jefferson to Henry Knox (Mar. 27, 1801), in 33 The PAPERs of Thomas JefFerson, supra note 18, at 466.

$67 \quad I d$. 
The only appointments he would acknowledge were those to judicial office, as those officers were "irremoveable [sic]."68 Seeking to show his reasonableness, Jefferson sometimes claimed, "[M]r[.] A[dams]'s best friends ha[d] agreed" that treating the appointments as nullities was "right." 69 Whether allies of Adams approved of Jefferson's tactic is unknown.

Even if some Federalists accepted the approach, others complained. In late March of 1801, a squib in the Philadelphia Gazette accused Jefferson of a "direct departure" from his inaugural speech: "He has had the imprudence to stop the commissions of several Justices of the Peace appointed by Mr. Adams . . . and to substitute some of the most ignorant and ill-qualified men in their stead." 70 Because the justices had five-year terms, the paper confidently predicted that the President "will be obliged to give up the commissions which have been thus illegally detained."71 The author seemed unaware that most of the justices had been recess- appointed.

Perhaps because this complaint was grounded on Jefferson's withholding of certain commissions, his defenders largely ignored the President's tactic. ${ }^{72}$ In April, The National Intelligencer argued that neither signing nor sealing a commission made an appointment. Like all "sealed" documents, delivery was essential to effectiveness. Because the commissions had not been delivered, the President had not violated the Constitution or done anything improper. ${ }^{73}$ Levi Lincoln, the Attorney General, forwarded the defense to Jefferson, admitting that he had yet to opine on Jefferson's actions. ${ }^{74}$ Lincoln complained that because few had paid any attention to Jefferson's actual actions, he had "not heard or seen a syllable on the subject."75 There seems no trace of any Lincoln opinion on the nullification stratagem.

Things stayed quiet until the winter. In December of 1801, William Marbury $^{76}$ and three others wrote to James Madison informing him that they

\footnotetext{
$68 \quad I d$.

69 Letter from Thomas Jefferson to William Branch Giles, supra note 50, at 414.

70 Philadelphia Gazette, Mar. 25, 1801, at 3.

$71 \quad I d$.
}

72 One exception was The National Intelligencer, which argued that the President had shown restraint in reappointing so many of the Adams's justices of the peace. See Nat'L Intelligencer, \& Wash. Advertiser, Mar. 23, 1801, at 2.

73 Nat'l Intelligencer, \& Wash. Advertiser, Apr. 3, 1801, at 1.

74 Letter from Levi Lincoln to Thomas Jefferson (Apr. 9, 1801), in 33 THE PAPERs OF Thomas JefFerson, supra note 18, at 557-58.

$75 \quad I d$. at 558.

76 The other petitioners were William Harper, Robert Townsend Hooe, and Dennis Ramsay. See Marbury v. Madison, 5 U.S. (1 Cranch) 137, 137-38 (1803). Because Marbury is the most famous petitioner, a brief sketch is in order. Marbury was a banker, investor, and a Federalist appointee in the Maryland and federal governments. Jefferson probably did not appoint Marbury because the latter was a hated financier and had tried to swing Maryland's electors to John Adams. See Forte, supra note 1, at 402. For a more complete portrait of Marbury, see generally $i d$. 
would ask the Supreme Court to order the delivery of their commissions. ${ }^{77}$ The very next day, Marbury and his associates filed suit. ${ }^{78}$

Interestingly, a member of the first Congress had predicted that someone might file such a suit. Representative William Smith of South Carolina had hoped that the first Congress would say nothing about removal in 1789, leaving it to a President to remove someone and have it tested in courts:

It will be time enough to determine the question when the President shall remove an officer .... I I conceive it can properly be brought before [the courts]; the officer will have a right to a mandamus to be restored to his office, and the judges would determine whether the President exercised a Constitutional authority or not. ${ }^{79}$

Smith was responding to James Madison (and others), who sought a congressional pronouncement indicating that the President had a power to remove. Though James Madison prevailed in the fight, securing legislation signaling that the President enjoyed a constitutional power to remove, Smith was right that one might file such a suit. But it was lodged against James Madison, as Secretary of State, and not the President.

The Supreme Court seemed to agree with Representative Smith that it could adjudicate the constitutional question, and quickly issued a rule directing Madison to explain why the Court should not order the delivery of the commissions. ${ }^{80}$ Some speculate that petitioners sought a writ of mandamus fully aware that the Court would conclude that it lacked jurisdiction, but also knowing that it would first declare that Adams had appointed the petitioners. $^{81}$

Because Congress barred the Court from sitting in 1802, ${ }^{82}$ Marbury $v$. Madison was not heard until 1803. Charles Lee, the Attorney General under Adams, argued for the plaintiffs that the appointments had vested once the commissions had been signed and sealed, and that the President lacked authority to remove the justices of the peace. ${ }^{83}$ While some members of the Jefferson Administration participated in the case, they did so as witnesses only, and did not defend the President. ${ }^{84}$ This made for a curious mix of respect and defiance on the part of the Administration. The Attorney Gen-

77 Letter from William Marbury to James Madison, Secretary of State (Dec. 16, 1801), in 2 The Papers of James Madison, supra note 24, at 319-20.

78 See Richard E. Ellis, The Jeffersonian Crisis 43 (1971).

791 Annals of Cong. 459 (1789) (Joseph Gales ed., 1834).

80 See Marbury, 5 U.S. (1 Cranch) at 138.

81 See Susan Low Bloch, The Marbury Mystery: Why Did William Marbury Sue in the Supreme Court?, 18 Const. Comment. 607, 625-26 (2001) (suggesting that Marshall and the Marbury plaintiffs may have orchestrated the suit in the Supreme Court).

82 See Judiciary Act of 1802, ch. 31, § 1, 2 Stat. 156; see also Cliff SloAn \& David McKean, The Great Decision: Jefferson, Adams, Marshall, and the Battle for the Supreme Court 113 (2009) (noting that Congress had barred Court from sitting in 1802).

83 Marbury, 5 U.S. (1 Cranch) at 137-38.

84 Id. at $142-43$. 
eral, Levi Lincoln, participated as a witness. ${ }^{85}$ James Madison, the defendant, flouted the Court's order to show cause. ${ }^{86}$

John Marshall's opinion never definitively said when Adams had appointed Marbury and the others. Instead, it declared that appointments might vest when sealed, when signed, or even earlier. ${ }^{87}$ Whatever the case, it was uncontested that the commissions had been signed and sealed. To show that the appointments necessarily had vested, Marshall rejected the notion that delivery to, or acceptance by, the appointee might vest the office, concluding that the appointment had to be complete prior to either event. ${ }^{88}$ Further, Marshall concluded that the President could not remove justices of the peace, basing his judgment upon a rather disputable implication of the five-year term of office found in the statute. ${ }^{89}$

Much of what Marshall said in Marbury could be ignored because the portion discussing the merits was dicta. ${ }^{90}$ And, in fact, both Marbury and Madison ignored it, each in his own way. After the case, Marbury never got his commission nor attempted to assume his office, despite the fact that his attorney had argued that Marbury already was in office. ${ }^{91}$ Madison seems never to have commented on the opinion, much less complied with its reasoning. ${ }^{92}$ Given that the Justices likely knew that Jefferson would ignore the first two parts of the Marbury opinion and the fact that the Court opined in the wake of the repeal of the Judiciary Act of 1801, the opinion should "be

\section{$85 \quad I d$.}

86 See McConnell, supra note 1, at 26 (claiming that failing to respond to the Court's rule dramatically signaled that the executive denied any claim that the Court could entertain a mandamus action against a cabinet officer).

87 Marbury, 5 U.S. (1 Cranch) at 160.

88 Id. at 162.

89 Marshall concluded that because the justices of the peace had statutory five-year terms, they did not serve at pleasure, but rather had a right to hold office "independent of the [E]xecutive." Id. This was consistent with his conclusion in 1801. See supra note 38. He never discussed the possibility that the justices of the peace had fixed terms, subject to presidential removal. Cf. Judiciary Act of 1789, ch. 20, § 27, 1 Stat. 73, 87 (establishing four-year terms for marshals and making clear that they served at the President's pleasure). The advantage of this reading of the statute is that it gives meaning to the fixed term (no one could stay in office beyond five years without a renewed appointment) without raising the constitutional question of whether Congress could limit the removal power that was thought to reside in the President. For Jefferson's view that the justices served at pleasure, see supra text accompanying notes 53-55.

In 1779, Jefferson took the view that the state justices of the peace served during good behavior, unlike colonial justices of the peace. See Letter from Thomas Jefferson to Unknown (Dec. 25, 1779), in 3 The Papers of Thomas Jefferson, supra note 18, at 242. The 1776 Virginia Constitution never expressly granted such tenure to justices of the peace and I have been unable to determine whether the legislature had conveyed it via statute.

90 Much later, the Court rejected Marshall's claim that the President lacked authority to remove the justices of the peace. See Myers v. United States, 272 U.S. 52, 139-40 (1926).

91 See Gregory E. Maggs \& Peter J. Smith, Constitutional law: A Contemporary APProACH 55 (2d ed. 2011).

92 See Sloan \& McKean, supra note 82, at 167-68. 
understood as the product of a defeated and demoralized Court," one straining for power and relevance..$^{93}$

In the immediate wake of the case, Jefferson apparently wrote nothing of it. Over decades, he was more voluble. In letters to friends, he insisted that Marshall was wrong to say that the justices of the peace who had not received commissions had been appointed. Everyone knew, Jefferson said repeatedly and insistently, that delivery was necessary to vest the office. ${ }^{94}$

Whatever the merits of this belated legal argument, the actual grounds for Jefferson's 1801 decision not to recognize the appointments had nothing to do with the non-delivery of some commissions. Recall that Jefferson's actions reflected an intense desire to treat the "indecent" midnight appointments as nullities. ${ }^{95}$ Whether Jefferson forgot the actual events is unknown. Perhaps looking back on the events years later led Jefferson to adopt the arguments found in the National Intelligencer, that delivery is necessary for an appointment to vest. This may have been for no other reason than that Marbury was only about individuals who did not receive their commissions; it did not address the status of those who had received them but nonetheless had their supposed appointments nullified.

Jefferson's nullification strategy, and the reaction to it, warrants further scrutiny, primarily because both have long been obscure and misunderstood. One might suppose that Jefferson treated the vast bulk of midnight appointments as nullities because he thought they had never been consummated. Perhaps he thought something had arrested their completion, like non-delivery of commissions. Yet there is no theory of appointment that could have sanctioned his course in 1801. Recall that he recess-appointed justices of the peace, including those who had received a commission, meaning that he treated delivery as irrelevant.

We are drawn to the question of whether he differentiated those who received commissions and those who did not because Jefferson, in 1807 and

93 McConnell, supra note 1, at 22.

94 See Letter from Thomas Jefferson to George Hay (June 2, 1807), in 10 The Works of Thomas Jefferson, supra note 2, at 396 n.I; Letter from Thomas Jefferson to Judge Spencer Roane (Sept. 6, 1819), in 12 id. at 135, 138; Letter from Thomas Jefferson to William Johnson, in 10 id. at 256 n.1.

Jefferson seemed less interested in the mandamus question. In his 1807 letter to District Attorney Hay, Jefferson denied that a court could order the executive to deliver a commission. See Letter from Thomas Jefferson to George Hay, supra, note 94, at 396 n.I. In 1808, his Attorney General opined that executive officers could not be mandamused with respect to "acts purely ministerial and executive in nature." Letter from the Attorney General to the President of the United States (July 15, 1808), in 1 AM. L.J. 433, 438 (John E. Hall ed., 1808). This was not a belated response to Marbury. Rather Caesar Rodney's opinion came on the heels of a circuit court opinion that had issued a writ of mandamus against a port collector. See id. at 433. The Rodney opinion emphasized that the statute in question granted discretion to the collector and to the President, perhaps indicating that a mandamus might be appropriate where there was no discretion. If that was Rodney's position, it did not deviate much from Marshall's opinion in Marbury, for the latter also distinguished acts of discretion from acts compelled by law.

95 See Letter from Thomas Jefferson to Benjamin Rush, supra note 55, at 436-37. 
thereafter, emphasized that distinction and because it was the focus of Marbury. But this focus is misplaced, at least if we wish to discern Jefferson's 1801 justification for his treatment of the midnight appointees. It seems reasonably clear that Jefferson's original justification had little to do with commissions, delivery, or when an appointment vests, and instead turned on whether the justices of the peace held tenure at the President's pleasure. Jefferson likely supposed that Adams had appointed the justices but thought that he could remove them from office and had in fact done so via the omnibus recess appointment commission.

First, Jefferson seemed to admit, repeatedly, that the justices of the peace were in office. Indeed, his draft 1801 letter to the midnight appointees instructed that "the appointment . . received" was to be treated as if it never had been made. ${ }^{96}$ He also referred to "appointments" two other times in that draft and in other letters that actually were mailed.

Second, in that same 1801 letter meant for the midnight appointees, he noted that they had been appointed "during the will of the President."97 When read in conjunction with the rest of the letter, this passage suggests that he was implicitly removing them. Why else mention that they held tenure at the pleasure of the President? A 1779 Jeffersonian letter about removing justices of the peace helps reinforce that inference. "Lawyers know that either estates or offices held during will are determinable by the slightest acts implying only, without positively expressing, a change of will. Hence the issuing [sic] a new commission of the peace determined the offices of those named in the former [commission]." 98 That is exactly what President Jefferson had done in 1801. Whether or not he had sent the letter to the Adams' appointees, he had issued a new omnibus justice-of-the-peace commission. The 1779 letter went on to state that those who were to continue in office had to be mentioned in the new commission. This was precisely the tack President Jefferson took. ${ }^{99}$ He recess-appointed only some of the existing justices of the peace, thereby removing all those who left unmentioned. ${ }^{100}$

So why did Jefferson repeatedly discuss treating the midnight appointments as "nullities"? By treating them as "nullities," Jefferson avoided having to admit that he had removed the justices of the peace. As he explained to Henry Knox, a colleague of Jefferson's from the Washington Administration, "in the class of removals ... I do not rank the new appointments which $[\mathrm{M}] \mathrm{r}[.] \mathrm{A}[$ dams] crouded [sic] in with whip \& spur from the 12th of Dec."101

96 Circular Letter from Thomas Jefferson to Midnight Appointees, supra note 18, at 173.

$97 \quad I d$.

98 Letter from Thomas Jefferson to Unknown, supra note 89, at 242.

$99 I d$.

100 Omnibus Commission to Justices of the Peace (March 18, 1801), in Bundy, supra note 26 , at 266 .

101 Letter from Thomas Jefferson to Henry Knox, supra note 66, at 466; see Letter from Thomas Jefferson to William Findley (Mar. 24, 1801), in 33 The PAPers of Thomas Jefrerson, supra note 18 , at $427-28$ (noting that he had to remove some officials and then declaring that he would consider the midnight appointments as "nullities"). 
Consistent with this stance, in his own list of removals, he left out the justices of the peace. ${ }^{102}$ Likewise, in his catalog of appointments and removals sent to the Senate in January of 1802, he did not list any of the justices as removed. ${ }^{103}$ Reflecting the success of his scheme, newspapers did not list them either. ${ }^{104}$

Jefferson's obfuscation was a success, in the sense that his treatment of the midnight appointees was not seen as an omnibus removal coupled with partial reappointment. But he paid a price for that approach because many erroneously supposed that he had somehow either blocked the appointments (prevented their consummation) or had (improperly) denied commissions for those lawfully in office. This affected the legal arguments. Commentators focused on when an appointment vested, saying nothing about removal. The plaintiffs said surprisingly little about removal, with Chief Justice Marshall saying even less. Logically, however, the removal question was no less important than whether Marbury and the others had been appointed, for if Jefferson had removed them from office, they no longer had a right to a commission.

Jefferson himself was not immune to the tactic's lingering effects. When Jefferson belatedly commented on Marbury in 1807, he said nothing about removal, focusing on delivery alone. He thereby ignored what seemed the actual justification for his actions in 1801 and also disregarded a potent and complete defense of his actions. So what seemed to be a wholesale removal of the non-Article III midnight appointees followed by a partial reappointment has gone down in history as a fight about when offices vest.

\section{Five Theories of When an Appointment Vests}

If I am right about Jefferson's original theory of the midnight appointments, removal should be no less important in any discussion of whether Jefferson's actions were legal. Although I believe Jefferson's implicit view about removal was correct-that the justices of the peace held five-year terms terminable at the President's pleasure-the rest of this paper concerns the plaintiffs' primary focus, namely when an appointment vests. Was Marshall correct that an appointment vested prior to delivery of a commission? Or was Jefferson on the mark when he claimed in 1807 that delivery of a commission was necessary for an appointment to vest?

Four constitutional provisions frame the dispute. First, the Appointments Clause provides that the President "shall nominate, and by and with the Advice and Consent of the Senate, ... appoint" all officers of the United

102 See List of Appointments and Removals (ca. May 1802), in 33 The PAPERs of Thomas Jefferson, supra note 18, at 668-69; List of Appointments and Removals (after May 10, 1803), supra note 63, at 670-72.

103 See Letter from Thomas Jefferson to the Senate, supra note 60, at 331-36 (listing various officers removed, noting recess appointments of justices of the peace, and not listing any of them as removed).

104 See, e.g., U.S. Oracle, \& Portsmouth Advertiser, Oct. 31, 1801, at 2. 
States. ${ }^{105}$ Second, Congress may vest the appointment of inferior officers with the President, the department heads, or the courts. ${ }^{106}$ Third, the President may appoint during the recess of the Senate, with the tenure of such an appointment expiring at the end of the next Senate session. ${ }^{107}$ Fourth, the President must commission all officers of the United States. ${ }^{108}$

Using text, structure, and early practice as yardsticks, this Part considers five answers to the question, "When does an appointment vest?" Those answers are: (1) when the Senate consents; (2) after the Senate consents, but prior to commissioning; (3) when a commission is signed or sealed; (4) when a commission is delivered to the appointee; and (5) when an individual accepts an offer of appointment. This Part focuses on the appointment of Senate-confirmed individuals, with little discussion of recess appointments and unilateral appointments to inferior offices.

\section{A. By the Advice and Consent of the Senate}

Some might suppose that the Constitution creates a default rule of automatic appointment. Under this theory, while nomination rests solely with the President, an appointment results automatically from the joint action of the President and the Senate. In particular, the President's "action" of keeping the nomination before the Senate (i.e., not withdrawing the nomination), combined with the Senate's consent, results in an appointment to office. Just as the House and Senate, acting together, pass bills, perhaps the President and the Senate, acting together, appoint officers. This rule is subject to the exceptions found in the Constitution, namely the President's ability to appoint during a Senate's recess, ${ }^{109}$ and Congress's ability to vest unilateral appointment authority over inferior officers. ${ }^{110}$

To make this automatic appointment theory concrete, consider a scenario: the President nominates a person to serve as an Article III judge. The Senate considers the nominee and advises and consents to her appointment. As soon as the Senate supplies its advice and consent, the appointment is complete because under the automatic appointment theory the Constitution provides that the appointment vests when the Senate consents. While the President must still commission the new judge (because the Constitution requires as much), the appointment is already made.

Had John Marshall endorsed the automatic appointment theory, his argument that William Marbury had been appointed would have been short and sweet. He might have said that President John Adams nominated and the Senate consented, thereby appointing Marbury and the others. Yet Marshall never made the assertion, much less discussed this possibility. Had he

105 U.S. Const. art. II, § 2, cl. 2.

106 Id.

107 U.S. Const. art. II, $\$ 2$, cl. 3.

108 Id.

109 Id.

110 U.S. Const. art. II, $\S 2$, cl. 2. 
wished to do so, he might have cited portions of The Federalist. When "Publius" spoke of the appointment power as confided "jointly" in the Senate and President, perhaps he endorsed the automatic appointment theory. ${ }^{111}$ Some of Jefferson's critics pressed the theory, insisting that the justices of the peace were appointed on March 3, when the Senate consented. As one put it, "the concurrence of the President and the Senate in naming to office, complete the act of appointment."112 The detractor added that the President had to commission those whom "he finds on the records of the Senate to have been appointed."113

While Jefferson's critics spoke in the context of a partisan row, others made similar claims at a time when they had no stake in the justice of the peace controversy. In 1799, a court martial sentenced Richard Hunt to death. ${ }^{114}$ Hunt complained that the proceedings were invalid because, among other things, members of the court had never received their commissions and hence were unable to conduct a court martial. ${ }^{115}$ President John Adams sought the advice of members of his Cabinet. The Treasury Secretary, Oliver Wolcott, claimed that the concurrent act of the Senate and the President constituted an appointment. ${ }^{116}$ Timothy Pickering, who as Secretary of State was charged with affixing the seal to civil commissions, agreed that appointments automatically vested when the Senate consented. ${ }^{117}$ So at least two members of the Adams Cabinet believed that the Senate's consent completed the appointment, with no further act necessary on the President's part. And while there was no consensus as to the precise moment of appointment, there was agreement in the Cabinet that the court martial judges had been appointed even though they lacked commissions and even though none were prepared. ${ }^{118}$ Though the episode occurred less than two years before Jefferson's actions in the spring of 1801, no member of the Adams

111 The Federalist No. 67, at 342 (Alexander Hamilton) (Garry Wills ed., 1982).

112 No. XVI, Addressed to the President of the United States, Courier OF N.H., Dec. 31, 1801, at 2; see also Executive Dismissal of a Judge, Republican, Mar. 5, 1802, at 2 (stating that "appointment [is complete], by the joint act of the President and the Senate").

113 No. XVI, Addressed to the President of the United States, supra note 112, at 4.

114 See Letter from James McHenry to Alexander Hamilton (July 25, 1799), in 23 THE Papers of Alexander Hamilton 286 (Harold C. Syrett ed., 1976).

115 Letter from John Adams to James McHenry, Secretary of War (June 5, 1799), in 8 The Works of John Adams 654 (Charles Francis Adams ed., 1853).

116 See Letter from Oliver Wolcott, Secretary of the Treasury, to James McHenry, Secretary of War (July 3, 1799), PApers of the War Department: 1784-1800, available at http:/ / wardepartmentpapers.org/docimage.php?id=33298\&docColID=36405.

117 See Letter from Timothy Pickering, Secretary of State, to James McHenry, Secretary of War (July 9, 1799), PAPers OF THE WAR Department: 1784-1800, available at http://war departmentpapers.org/docimage.php?id=33442\&docColID=36553.

118 See Letter from Timothy Pickering, Secretary of State, to James McHenry, Secretary of War, supra note 117; Letter from Benjamin Stoddert, Secretary of the Navy, to James McHenry, Secretary of War (July 6, 1799), Papers of the War Department: 1784-1800, available at http://wardepartmentpapers.org/docimage.php?id=33373\&docColID=36481; Letter from Oliver Wolcott, Secretary of the Treasury, to James McHenry, Secretary of War, supra note 116. 
Administration seems to have brought it to light during the Marbury controversy. Indeed, no one seems to have discussed the episode at all either during 1801-1803 or in modern times.

Evidence for the automatic appointment theory also comes from an improbable source: the presidency of James Madison. Less than a decade after Marshall admonished President Jefferson and Secretary of State Madison, President Madison wrote a letter that seemed to endorse the automatic appointment theory. After noting that he had nominated William Eustis to serve as Secretary of War, Madison observed that the "Senate have compleated [sic] the appointment." 119 Though a commission accompanied the letter to Eustis, Madison's language suggests that he believed the Senate's consent made the appointment.

The automatic appointment theory rests on a plausible reading of the Constitution. After all, the text speaks of the President appointing "by . . . the ... Consent of the Senate." 120 This language could be read to indicate that while the President appoints, he does so via the Senate's consent. The President might withdraw a nomination pending before the Senate. But once the Senate consents to a nomination left before it, the appointment is made, or so the automatic appointment theory supposes.

Yet the theory suffers from some insuperable difficulties. The full Clause speaks of appointing "by and with the Advice and Consent of the Senate," 121 a phrase that suggests that the Senate merely consents to the appointment and advises the President to consummate it. Had there been a desire to make the office vest upon the Senate's consent, other text could have accomplished that purpose, something like: "The President shall nominate to office, with the Senate's consent completing the appointment."

Moreover, "advice and consent" comes from English enactment clauses. The Crown would make law "by and with the advice and consent" of the two chambers. ${ }^{122}$ A law was not made merely because both chambers passed it. Rather, the Crown retained a right to veto bills presented to it. ${ }^{123}$ If "advice and consent" permitted the Crown's rejection of bills, it would be odd to repeat the phrasing in the Constitution and expect it to operate differently with respect to appointments.

Finally we have evidence from practice to suggest that the automatic appointment theory is mistaken. The Treaty Clause, which has similar phrasing (" $[\mathrm{h}] \mathrm{e}$ shall have Power, by and with the Advice and Consent of the Senate, to make Treaties" ${ }^{124}$ ), is read as authorizing the President to make or ratify treaties only with the Senate's advice and consent, not as indicating that the treaty is made by virtue of the Senate's consent. Early Senates would

119 Letter from James Madison to William Eustis (Mar. 7, 1809), in 1 The PAPERs of James Madison, supra note 24, at 26.

120 U.S. Const. art. II, § 2, cl. 2.

121 Id. (emphasis added).

1221 William Blackstone, Commentaries on the Laws of England 85 (1765).

123 Id. at $177-78$.

124 U.S. Const. art. II, § 2, cl. 2. 
"consent" to the treaty and "advise the President of the United States to ratify the same."125 Similarly, early Senates would "advise and consent to the appointment," 126 a locution suggesting that the Senate consented to an appointment to be made in the future by the President. That is to say, the Senate seemed to acknowledge that while its consent was a precondition, the consent did not complete the appointment.

\section{B. After the Senate Consents, but Before Commissioning}

In Marbury, the Chief Justice claimed, as an initial matter, that appointing was distinct from commissioning. ${ }^{127}$ Besides noting that the acts were discussed in different sections of Article II, Marshall observed that the Constitution seemingly required the President to commission all officers, including those appointed by department heads and the courts. ${ }^{128}$ Marshall believed that because the President had to commission officers appointed by others, that proved that the acts of appointing and commissioning were necessarily separate. It was a clever argument, yet one somewhat blunted by his admission that, whatever the Constitution might seem to require, in practice Presidents only commissioned their appointees. ${ }^{129}$

Perhaps Marshall was aware that others had made similar claims about the distinctiveness of appointing and commissioning. In 1802, an author critical of Jefferson's treatment of another supposed appointee of John Adams reluctantly admitted that "some [separate] act of appointment is necessary on the President's part," 130 even after Senate consent. Believing that John Adams had appointed the judge in question, the critic asked, "[i]s not the order to the Secretary of State to make out and deliver a commission, such an act of appointment?"131 Another critic claimed that because the Constitution said that the President must commission "all the officers," it implied that all those receiving commissions must already be officers-in other words, have been appointed prior to commissioning. ${ }^{132}$

This theory supposes that the President appoints via an act distinct from Senate consent and presidential commissioning. It is focused on the sequence of events (nomination, Senate consent, appointment, commissioning) and does not specify what the President must do to appoint.

Consider this scenario: the President nominates an individual to serve as Treasury Secretary and the Senate consents. Under this theory, the nominee

125 E.g., 1 Journal of the Executive Proceedings of the Senate of the United States of America, supra note 34, at 9.

126 E.g., id. at 44. Admittedly, had the Senate provided that it "consented" to the appointment and "advised the President to appoint," the point would be clearer still.

127 See Marbury v. Madison, 5 U.S. (1 Cranch) 137, 155-56 (1803).

128 Id. at 156.

129 Id. (admitting that the Commissions Clause "may never have been applied to officers appointed" by others).

130 Executive Dismissal of a Judge, supra note 112, at 3.

131 Id.

132 No. XVI, Addressed to the President of the United States, supra note 112, at 4. 
is not yet Treasury Secretary. Furthermore, the President can issue no commission until the appointment has been made because appointment must precede commissioning. If the President orders someone to assume an office, that order signals that the appointment has been made, for the President would not issue such an order without first appointing the person. Likewise, if the President notifies the Senate of an appointment, that announcement signals that the appointment is complete.

Looking to early practice, some of President George Washington's letters discussed appointment as occurring after Senate consent but before signing any commission. In one he wrote, "I do hereby appoint you [the recipient]" to the command of a revenue cutter, and that a commission would follow upon acceptance of the office. ${ }^{133}$ In another missive, Washington informed someone of his appointment, with a commission issuing only much later. ${ }^{134}$ Believing that rapid appointments were necessary, Alexander Hamilton once claimed that Washington could appoint without delay, with "antedated" commissions issued later. ${ }^{135}$

Ironically, Thomas Jefferson knew that it was possible to appoint without signing or delivering a commission. As Washington's Secretary of State, Jefferson issued the antedated commissions that Hamilton had recommended, meaning Jefferson should have known that Washington had already appointed those people to office. More tellingly, the first Secretary of State had opined on this very issue. In the course of telling Washington that only the President (and not the Senate) could decide a diplomat's destination (e.g., England) and grade (e.g., ambassador), Jefferson declared that the Constitution established a "natural order" of nomination, appointment, and commission. ${ }^{136}$ "[A] ppointment does not comprehend the neighboring acts of nomination, or commission," he insisted. ${ }^{137}$

Jefferson's actions as President also indicated that appointments could vest prior to commissioning. In a July 1801 letter to the Governor of the Mississippi territory, Jefferson told him that he had "appointed" a consul at New Orleans. ${ }^{138}$ The commission was not issued until days later, ${ }^{139}$ meaning that the appointment occurred prior to commissioning or any delivery. But

133 Letter from George Washington to William Cooke (Apr. 25, 1791), in 8 The PAPERS of George Washington 134 (Dorothy Twohig et al. eds., 1999).

134 Letter from George Washington to Benjamin Lincoln (Aug. 20, 1789), in 3 THE Papers of George Washington 502 (W.W. Abbot et al. eds., 1989) ("I . . have appointed you."); George Washington, Proclamation to the Southern Indians (Aug. 29, 1789), in 3 id. at 567 ("I have ... appointed and Constituted, And I do appoint and constitute by these Presents . . Benjamin Lincoln.").

135 Letter from Alexander Hamilton to George Washington (July 26, 1792), in 10 THE Papers of George Washington 577 (Philander D. Chase et al. eds., 2002); see also Letter from Tobias Lear to Thomas Jefferson (Oct. 26, 1792), in $11 \mathrm{id}$. at 264-65 (requesting backdated commissions for those already appointed).

136 Thomas Jefferson, Opinion on the Powers of the Senate Respecting Diplomatic Appointments, supra note 22, at 379.

137 Id.

138 Letter from Thomas Jefferson to William C. Claiborne, supra note 25, at 561. 
there is an even earlier episode of President Jefferson partially confirming what Secretary of State Jefferson said and did. Within days of his decision to withhold (and presumably dispose of) those justice of the peace commissions that remained in the Department of State in the wake of his inauguration, Jefferson issued an omnibus commission to the justices of the peace that he had recess-appointed. The relevant portion of the commission reads as follows: "I have appointed you jointly and severally" justices of the peace. ${ }^{140}$ The past tense suggested that Jefferson had appointed them prior to the signing or delivery of the commission. ${ }^{141}$ Whereas Jefferson would insist later that delivery was necessary to appoint, in the wake of treating the midnight appointments as nullities he seemed to appoint some of those same justices prior to commissioning them, much less delivering a commission.

\section{Commissioning}

Recall that Chief Justice Marshall speculated that signing or sealing the commission might make the appointment. Others had voiced similar views, even prior to that case. Before ultimately concluding that a commission was mere evidence of an appointment, John Adams speculated in June of 1799 "whether the signature of the commission is not the act of appointment."142 If so, that meant that Adams had not appointed those judges who had sentenced Richard Hunt to death because, as discussed earlier, no commissions had been made out. ${ }^{143}$

This commission theory posits that the satisfaction of the President's duty to commission simultaneously completes the appointment. There is plenty of evidence that Presidents appointed via commissions. In a 1790 diary entry, Washington wrote that he had appointed two diplomats via "sign[ing]"144 their commissions. Likewise, the commissions he granted to the first Supreme Court Justices read, "I . . . do appoint him," ${ }^{145}$ a present tense locution that insinuated the commissions appointed. Occasionally, commissions would read, "[I] hereby appoint" individuals to an office, clearly indicating that the commission was the instrument of the appointment. ${ }^{146}$

139 Letter from Robert Smith to Thomas Jefferson (July 13, 1801), in 34 The PAPERs OF Thomas Jefrerson, supra note 18, at 561-62 (editors' note) (noting that Clark's commission was dated July 16, 1801).

140 Omnibus Commission to Justices of the Peace, supra note 100, at 266.

141 Id.

142 Letter from John Adams to James McHenry (June 19, 1799), in 8 The Works of John Adams, supra note 115, at 659.

143 See supra text accompanying notes 114-18.

144 George Washington, Tuesday, April 21, 1790, in 6 The Diaries of George WashingTON 64 (Donald Jackson \& Dorothy Twohig eds., 1979).

1451 Documentary History of the Supreme Court of the United States, 1789-1800, at 10, 50, 78 (Maeva Marcus \& James R. Perry eds., 1985) (commissions for John Jay, James Wilson, and Thomas Johnson).

146 George Washington, Commission (Jan. 22, 1791), in 7 The Papers of George Washington, supra note 133, at 259 (appointing Thomas Johnson, Daniel Carroll, and David Stuart). 
Judging by the extant commissions, it seems that the dominant locution was "I do appoint" an individual to office, suggesting that the predominant means of appointment was via commission.

Jefferson should have known that commissions could serve as a means of appointing. With respect to the Washingtonian commissions for the Supreme Court Justices, ones that used the "I do appoint" language, a statute required Jefferson to affix the seal of the United States to them. ${ }^{147}$

Moreover, on his second day of office, President Jefferson issued a commission to James Madison which read, "I have nominated, and . . . do appoint him Secretary of State." 148 If this language is to be believed, Jefferson appointed Madison via the commission itself, not waiting until delivery to Madison. This was not some anomaly, for President Jefferson (and Secretary of State Madison) issued many such commissions. In 1807, around the same time he claimed that delivery of a commission was essential to appoint to office, ${ }^{149}$ Jefferson issued a commission that read, "I do by these presents appoint" 150 William Clark as Brigadier General of the Louisiana militia. Jefferson ought to have read the commissions prior to affixing the seal to them as Secretary of State and prior to signing them as President. Had he done so, he would have seen that commissions sometimes served as instruments of appointment.

If commissioning completed the appointment, was it the signature, the affixing of the seal, or some other part of the commissioning process that ensured completion? For good reason, John Marshall, in Marbury, struggled to supply an answer. The Constitution does not detail what the President must do to "commission" an officer. Presumably, he must issue a written document with an individual named, provide that the individual has been, is, or will be given a particular office, and sign that document. Perhaps the President also must take measures to ensure that the commission is regarded as an official document. Early Washington commissions indicated that he had affixed the seal of the United States, as federal law required. ${ }^{151}$ Even if the statute had said nothing, however, something like a sealing requirement may have arisen from the Constitution itself, for such steps help validate the commission in a way that a signature, by itself, might not. The President's signature might have been hard to forge; similarly, a seal was perhaps difficult to replicate. Put a signature and a seal together and the authentication might seem airtight.

147 Act of Sept. 15, 1789, ch. 14, § 5, 1 Stat. 68, 68-69 (creating the State Department).

148 Commission to the Office of Secretary of State, supra note 24, at 2.

149 See Letter from Thomas Jefferson to George Hay, supra note 94, at 396 n.I.

150 Coues, supra note 27, at lxxiii.

151 See Act of Sept. 15, 1789, ch. 14, 1 Stat. 68. The statute imposed the duty upon the Secretary of State. Washington performed that duty in several circumstances while the office was vacant. 


\section{Delivery}

The delivery theory rests upon common law concepts applicable to deeds and related instruments and contends that without commission delivery, the President has not filled the office or made an officer. ${ }^{152}$ The delivery theory has two rather different guises.

In Marbury, Marshall supposed that the President had to complete the entire act of appointment without the aid of others, the theory being that the Constitution granted the appointment power to the President alone. ${ }^{153}$ As Marshall put it, "appointment is the sole act of the President" 154 because under the Constitution the appointment is "to be made by the President personally." 155 Based on this belief, he ruled out delivery to the appointee because the President never personally delivered commissions. ${ }^{156}$ Instead, he focused on delivery to the Secretary of State: "If then the act of livery be necessary to give validity to the commission, it has been delivered when executed and given to the secretary" 157 to the appointee. That is to say, if delivery mattered, delivery to the Secretary of State made the appointment.

Jefferson and his defenders had a different delivery theory in mind, one where delivery to the putative appointee was crucial. In 1807, Jefferson wrote that for a "commission, a deed, a bond, delivery is essential to give validity. Until ... the commission is delivered out of the hands of the Executive \& his agents, it [the office] is not his [the potential appointee's] deed. [The President] may withhold or cancel it at pleasure . ..."158 The point would stick with Jefferson, for in 1823 he continued to insist "if there is any principle of law never yet contradicted, it is that delivery is one of the essentials to the validity of a deed." 159 Even if signed and sealed, "as long as it remains in the hands of the party himself, it is in fieri [pending] only, it is not a deed, and can be made so only by its delivery." 160 Though Marbury and his fellow applicants rejected Jefferson's version of the delivery theory, the fact that they sought commissions and had never tried to assume office without them

152 One might characterize the delivery theory as a subset of the commission theory if one believed that the President does not actually commission anyone until and unless the potential officer receives the commission. Under this theory, signing and sealing a commission does not actually satisfy the commission duty of the Constitution. There is much to be said for this understanding of the duty to commission because it is hard to see how anyone benefits from a constitutional obligation to sign and seal a document that is never actually given to the officer. See infra text accompanying notes 231-36. For our purposes, it does not matter whether one characterizes the delivery theory as a separate appointment theory or merely as a subset of the commission theory discussed in supra Section II.C.

153 Marbury v. Madison, 5 U.S. (1 Cranch) 137, 159-60 (1803).

154 Id. at 160; see also id. (describing appointment as "the mere act of the President").

155 Id. at 159.

$156 I d$.

157 Id.

158 See Letter from Thomas Jefferson to George Hay, supra note 94, at 396 n.I.

159 Letter from Thomas Jefferson to William Johnson, supra note 2, at 256 n.I.

160 Id.; see also Letter from Thomas Jefferson to Judge Spencer Roane, supra note 94, at $135,138$. 
lent it some plausibility. One might suppose that they wanted commissions to remove all doubts that they had been appointed. But insecurity about their status may have arisen because they lacked commissions, an uncertainty that suggested the importance of delivery. ${ }^{161}$

With the Jeffersonian delivery theory in mind, consider the hypothetical: The President nominates, the Senate consents, and the President signs and seals the commission for a potential federal marshal. There still is no appointment. Even after the President directs delivery and the commission is in transit, the appointment is not made until receipt by the would-be marshal. If the commission is lost and never found, the office is not vested. Another commission must be made out and actually delivered. In contrast to the sequence suggested by Secretary of State Jefferson in an early opinion to Washington (nomination, appointment, commissioning), ${ }^{162}$ President Jefferson's 1807 delivery theory contemplates a different sequence: nomination, commissioning, and then appointment (via delivery of the commission to the appointee).

The Jeffersonian delivery theory had some evidence to commend it. First, the statute requiring the Secretary of State to affix the seal suggested that even after a commission was made, an appointment was not complete. The law (which Marshall quoted in Marbury) provided that the Secretary had to "affix the said seal to all civil commissions, to officers of the United States, to be appointed by the President." 163 The provision, passed during the first session of the first Congress, could be read to suggest that appointment followed commissioning because the statute discussed individuals "to be appointed" after the seal was affixed to the commission.

Second, the Constitution's text had similar hints, or so one of Jefferson's defenders argued. In April of 1801, within weeks of Jefferson's decision to treat the Adams appointments as nullities, a good Republican rose to Jefferson's defense with respect to the charge of "illegally withholding the commissions." 164 The partisan focused on the Recess Appointments Clause: The President "shall have Power to fill up all Vacancies that may happen during the Recess of the Senate, by granting Commissions which shall expire at the End of their next Session."165 Jefferson's defender argued that this language showed that recess appointments-filling up vacancies during the Senate's

161 Of course some officers might be unable to produce a previously delivered commission because it was lost or destroyed. So delivery alone would not necessarily remove all doubts about whether a person was an officer. One could imagine a "possession" theory where appointment and continuation in office was tied to possession of a commission. In the course of rejecting the delivery theory, Marshall ridiculed the idea that delivery to the person might matter, for then "fraud, fire, or theft, might deprive an individual of his office." Marbury, 5 U.S. (1 Cranch), at 160. But the 1807 Jeffersonian delivery theory did not turn on continued possession; it turned on delivery alone.

162 Thomas Jefferson, Opinion on the Powers of the Senate Respecting Diplomatic Appointments, supra note 22, at 379.

163 Act of Sept. 15, 1789, ch. 14, § 4, 1 Stat. 68, 68.

164 The Nat'l Intelligencer, \& Wash. Advertiser, Apr. 3, 1801, at A1.

165 U.S. Const. art. II, § 2, cl. 3. 
recess-were to be made by the act of "granting commissions." 166 What was true for recess appointments was true for appointments more generally, or so the defender insisted. A grant of a commission, the author claimed, meant delivery; anything short of delivery could not constitute "granting Commissions." While a commission was in the executive's hand, he could "stop short" and choose neither to grant it nor make the appointment. ${ }^{167}$ Such a system of appointing made sense, said the writer, for information about a candidate's " $[\mathrm{k}]$ navery, partiality, or innocent mistake" might come to light after signing and sealing the commission, but prior to delivery. ${ }^{168}$ Despite the fact that the Attorney General sent this defense to Jefferson, ${ }^{169}$ no one in his administration made it at the time or thereafter.

In 1833, John Marshall endorsed the delivery theory as applied to pardons. Writing for the Court, Marshall claimed in United States v. Wilson that a pardon became effective only upon delivery. "A pardon is a deed, to the validity of which delivery is essential ...."170 Marshall never commented on this apparent inconsistency with Marbury. Perhaps Marshall thought pardons and appointments were rather different, with only the former requiring delivery to the beneficiary. Or maybe he did not pause to consider what his claim about pardons suggested about his earlier, more famous opinion about appointments.

Whatever the case may be, there is little evidence that many thought that delivery of a commission was essential to make an appointment. Certainly Jefferson's predecessors did not believe as much. As noted, Washington claimed to have appointed individuals prior to the making of any commission. ${ }^{171}$ He also asserted that he had appointed via the commission itself, prior to any delivery. ${ }^{172}$ Likewise, in the wake of the Richard Hunt court martial, all members of the Adams Cabinet concluded that an appointment could be made without issuing a commission, meaning that delivery could hardly be requisite. ${ }^{173}$ President Adams had come to the same conclusion, claiming that a commission was evidence of the appointment and not the appointment itself. ${ }^{174}$

166 The Nat'l Intelligencer, \& Wash Advertiser, Apr. 3, 1801, at A1 (emphasis omitted).

167 Id.

$168 I d$.

169 Letter from Levi Lincoln to Thomas Jefferson (Apr. 9, 1801), supra note 74, at 557.

170 United States v. Wilson, 32 U.S. (7 Pet.) 150, 161 (1833).

171 Letter from George Washington to Thomas Jefferson (Oct. 13, 1789), in 4 THE Papers of George Washington 174 (W.W. Abbot et al. eds., 1993).

172 Commission (Jan. 20, 1791), in 7 The Papers of George Washington, supra note 146 , at 258 .

173 See supra text accompanying note 118.

174 Letter from John Adams to J. McHenry (July 13, 1799), in 8 The Works of John Adams, supra note 115, at 665 . 
There is also little evidence that President Jefferson thought that delivery was essential to an appointment. ${ }^{175}$ As noted, Jefferson spoke of individuals being appointed prior to any commission being made out, much less delivered. ${ }^{176}$ His commissions also discussed appointments as having been made by the commission and not by its delivery. ${ }^{177}$ In adopting these conclusions, perhaps President Jefferson drew on his experience as Secretary of State. Maybe he also recalled what transpired in late 1789. Though Washington appointed Jefferson on September 26, 1789, Jefferson received his commission in late November, upon his return from France. ${ }^{178}$ In sum, Jefferson's 1807 claim that delivery to the putative appointee was essential is belied by his actions as Secretary of State and President.

\section{E. Acceptance}

Jefferson never argued that acceptance of the office was necessary to appoint. Marshall raised the issue sua sponte out of a sense that he should canvas all the arguments, especially since Madison had ignored the Court's order to explain why a writ of mandamus should not issue. ${ }^{179}$

The acceptance theory posits that someone cannot be appointed to office against her will, meaning that the President (and other appointers)

175 The editors of the Thomas Jefferson Papers discuss an interesting episode during the Washington Administration that might suggest that both Washington and Jefferson thought commission delivery was necessary to appoint. After the Senate consented to the appointment of Joseph Anderson as a territorial judge, allegations of Revolutionary War improprieties arose against him. Washington forwarded these allegations to Jefferson and requested his opinion on the matter. Jefferson concluded that the evidence favored Anderson and Washington agreed, with a commission issued to Anderson. See generally The Judicial Appointment of Joseph Anderson, Editorial Note, in 19 The Papers of Thomas Jefrerson, supra note 18, at 381-402 (narrating the contentious appointment of Joseph Inslee Anderson to civil office). This episode might suggest that neither Washington nor Jefferson thought the appointment was complete until the delivery of Anderson's commission. Yet there is little to support this inference. The actions of Washington and Jefferson can be read as supporting the delivery theory only if a commission had been signed and sealed at the time of their discussion. After all, if a commission had not been signed or sealed, that fact (and not the absence of delivery) could explain why neither Washington nor Jefferson believed the appointment was complete at the time Washington asked for Jefferson's opinion. There is nothing in the records indicating that Anderson's commission had been signed or sealed prior to the discussion between Washington and Jefferson. Moreover, because in other cases both Washington and Jefferson repeatedly acted as if delivery was not necessary to make an appointment, it makes little sense to think that either thought that anything turned on delivery.

176 See supra text accompanying notes 138-40.

177 See supra text accompanying note 140-41.

178 See Elmer Plishke, U.S. Department of State 42 (1999); Letter from George Washington to Thomas Jefferson (Nov. 30, 1789), in 4 The Papers of George Washington, supra note 171, at 341 (noting that commission had been sent to Virginia).

179 Marbury v. Madison, 5 U.S. (1 Cranch) 137, 160 (1803). Marshall said the Court had to consult its own "imagination" in an "anxious[ ]" quest for principles that might suggest the Court's view of when an appointment vests was mistaken. Id. at 159. 
cannot unilaterally appoint to office. So even after the President nominates, the Senate consents, and a commission is made out and delivered, the potential officer may still refuse the office and prevent her appointment. Moreover, the acceptance theory does not require any commission, focusing instead on acceptance of the office. Consider the following: the President nominates, and after securing the Senate's consent, offers the office of Supreme Court Justice to a lawyer. Whether or not a commission has been made out or delivered is irrelevant to whether the President has appointed the lawyer. Offer and acceptance, though insufficient to satisfy the President's commission obligation, does make an appointment.

There is much to be said for this theory. After all, theories that do not turn on acceptance contemplate that people are appointed even if they reject the office and never carry out any official functions. In such cases, competing theories that do not require acceptance envision an appointment followed by a quick resignation, when most people might conclude that the person never really was in office and hence was never appointed.

Nevertheless Marshall rejected the acceptance theory. He claimed that because the appointment power rested with the President, he had to be able to exercise it unilaterally, without regard to acceptance by a putative officer. ${ }^{180} \mathrm{He}$ also noted when a person appointed "refuses to accept that office, the successor is nominated in the place" 181 of the person declining the office, implying that the person refusing the office had occupied it nonetheless. He also claimed that the salary of the officer "commences from his appointment, not from" any delivery of the commission or acceptance of the office. $^{182}$

Marshall was generally correct about early practice. As the Chief Justice claimed, people concluded that the President had appointed even when the persons so appointed declined the office. ${ }^{183}$ Moreover, subsequent individuals were nominated to fill the vacancy occasioned by the resignation that was implicit in the declination.

Consider Robert Harrison's refusal to serve on the Supreme Court. In his letter to Washington explaining his decision, Harrison acknowledged his appointment and the honor it bestowed upon him, meaning that Harrison understood that Washington had appointed him without his consent. ${ }^{184}$ Similarly, Washington subsequently told the Senate that among those who had been "appointed" during the last session were some who had "declined serving." 185 In his list of new nominations, Washington recorded Robert

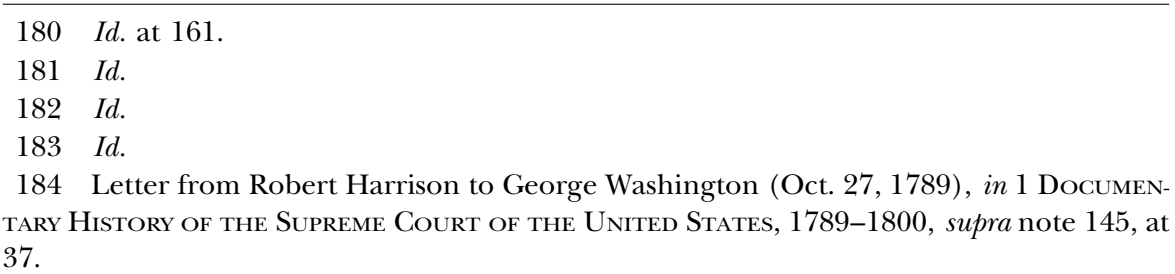

185 Letter from George Washington to the Senate of the United States of America (Feb. 9, 1790), in 5 The Papers of George Washington 121 (Dorothy Twohig et al. eds., 1996). 
Harrison as resigning from the Court and James Iredell as his new nominee. ${ }^{186}$ And in Washington's letter to Iredell, he noted that the office had become vacant via resignation of the "Gentlemen appointed."187

Yet despite these practices, acceptance had to matter in certain cases. Imagine that a federal statute prohibits a judge from occupying two judicial posts. Further, suppose the President purports to appoint a current district judge to a circuit court. Does the appointment automatically divest the individual of their district judgeship, even against their will? It cannot do so. If it could, a devious President could temporarily "promote" a disfavored judge via a recess appointment to a higher court (thereby divesting him of his current office) and then decline to send his name to the Senate for the permanent position.

Or consider a more realistic scenario. Suppose the President appoints a sitting Senator to the Supreme Court during the Senate's recess. The Constitution forbids sitting members of Congress from simultaneously serving as officers of the United States. If the President can appoint the Senator to the Supreme Court without the latter's consent, the President has effectively forced the Senator's resignation from the Senate.

Finally, there are state constitutional prohibitions on dual office holding. Almost all states bar at least some of their officers from serving in the federal government. ${ }^{188}$ If the President can force a federal appointment on a state official, the federal office would automatically divest the individual of her state post. Essentially, the President would have power to oust a governor or state assembly speaker by granting a minor federal appointment during a Senate recess.

The point is that in certain situations, it makes little sense to suppose that the President can involuntarily divest someone of their current office or station by appointing them to a new office. If that is so, then perhaps acceptance is sometimes necessary for an appointment to vest.

There is evidence that members of the Jefferson administration thought that acceptance was sometimes crucial. At the end of his administration, John Adams had tried to appoint Ray Greene to the Rhode Island district court. One problem was that Greene's commission was made out as if he had been appointed to the circuit court. Yet the Senate had never consented to such an appointment. But an even greater difficulty was that the district court judgeship was occupied at the time of the attempted appointment. Prior to leaving office, Adams had tried to appoint the existing district judge, Benjamin Bourne, to the circuit court. Yet Bourne did not accept the pro-

$186 I d$.

187 Letter from George Washington to James Iredell (Feb. 13, 1790), in 1 Documentary History of the Supreme Court of the United States, 1789-1800, supra note 145 , at 66.

188 For a discussion and summary of the many state-level incompatibility rules that bar dual state and federal office-holding, see Steven G. Calabresi \& Joan L. Larsen, One Person, One Office: Separation of Powers or Separation of Personnel?, 79 Cornell L. Rev. 1045, 1151-52 (1994). 
motion until March 23 of 1801. Based on these facts, Levi Lincoln declared that there was "no vacancy" in the district court when Adams had attempted to appoint Ray Greene. ${ }^{189}$ By deciding that Bourne had remained a district judge until March 23rd, Lincoln concluded that no Article III judge could be divested of his office merely by a supposed appointment to another office.

\section{The Making of Appointments Under the Constitution}

As we have seen, early commentators were quite divided. Some argued that an office vests upon the Senate's consent. Others claimed that appointments were made after Senate consent but before the issuance of a commission. A third cohort asserted that to commission someone was to appoint them. Still others contended that delivery made the appointment. And some, like Thomas Jefferson, endorsed different views over time.

Early practice was similarly divergent. Some officers were appointed without any commission being made. Others, Jefferson included, were appointed after a commission had been made out but before receiving it. In other cases, the President claimed to appoint via a commission. And in one case, acceptance was deemed crucial.

The dissonant voices and varied practices may lead some to conclude that the Constitution says anything about the matter. Perhaps those searching for a right answer are asking too much of a Constitution written in general terms and incapable of answering all disputed questions.

While this conclusion has its merits, it fails to consider another possibility. Perhaps each theory is right insofar as each provides a possible way of appointing officers. Perhaps each is wrong insofar as each purports to offer an exclusive means of appointing. Maybe the Constitution permits variation in appointment methods, ceding appointers significant discretion in how and when they appoint.

This Part offers a discretionary theory of appointment, a theory that accounts for the variations in early practice. This discretionary theory posits that the Constitution never enshrines a single method by which appointments become valid. Instead, the appointer has flexibility in deciding the means and methods of appointment.

The Part also considers application of the discretionary theory to other constitutional powers where the means and methods of their exercise are not obvious, such as pardons, orders to executive officers, and exercises of the judicial power. It also addresses constitutional restrictions on the general rule of appointer discretion. Next, it turns to a discussion of commissioning in greater depth and the role that commissions can serve as evidence of the appointment. Then it considers whether Congress may dictate, via statute, how and when an appointment vests. Finally, it reconsiders the appointment methods discussed in Part II in light of the discretionary theory and argues that none of them should be viewed as the exclusive means of appointing.

189 See Letter from Levi Lincoln to Thomas Jefferson (Apr. 8, 1801), in 33 THE PAPERS of Thomas Jefrerson, supra note 18, at 553 . 


\section{A. The Discretionary Theory of Appointment}

The early use of multiple means of appointing officers suggests a possibility left unmentioned in the Constitution's early years. Because the Constitution never dictates how or when an appointment is made, an appointment vests however and whenever the appointer decides that it should vest. This is the best answer because it makes sense of practice and the Constitution's text and structure.

The textual and structural case for the discretionary theory is simple. Article II grants the President the power to appoint, but it does not decree when or how such appointments are to be made. Nor does it elsewhere declare that someone else must dictate, in the first instance, how or when an appointment vests. The natural supposition is that the person empowered may decide such matters, for the power is given without any indication that others may specify these details.

The conclusion follows from principles related to incidental authority under agency law. We the People are the principals. The actors created by the Constitution are our agents. We the People have delegated, over time, certain powers to those agents. We have placed procedural (e.g., bicameralism, presentment, Senate consent) and substantive (e.g., the Bill of Rights) constraints on the exercise of these powers. Beyond such constraints, our agents may decide how and when to exercise the powers delegated to them so long as they continue to act in the best interests of their principals, because such authority is incidental to the express grant. There is an "inescapable proposition that it is not necessary . . . to spell out every detail in granting express authority" to an agent. ${ }^{190}$ This principle applies just as forcefully to the Constitution.

Because the Constitution contemplates various appointers, and because the appointer, under the discretionary theory, may decide how and when her appointments will vest, each appointer may choose her own method of appointment. When the President is the appointer, she may decide when her appointments shall vest. When appointing a Secretary, the President can decide that the appointment vests when the Senate consents. Or she may decide the offices vest with the delivery of a commission. If she wishes to recess-appoint someone, the President might choose to have the appointment vest if, and only if, the appointee accepts the office.

Others who may appoint inferior officers (department heads and courts) pursuant to statutory grants also may choose the manner and timing of their appointments. ${ }^{191}$ Similarly, because each chamber may select its own officers, ${ }^{192}$ each may decide what, if anything, must be done as a formal matter after the chambers vote on those officers. In this way, the Constitu-

190 William A. Gregory, The Law of Agency and Partnership $§ 14(\mathrm{D})$, at 40 (2001); see Restatement (Third) Of Agency $\$ 2.02$ (2006) (discussing how agents have incidental and necessary powers to pursue a principal's objectives).

191 U.S. Const. art. II, § 2.

192 U.S. Const. art. I, §§ 2-3. 
tion contemplates multiple appointers, each of whom may choose to appoint in multiple ways.

\section{B. The Discretionary Theory Applied to Other Provisions}

This discretionary theory of appointment derives from a general and underappreciated rule of constitutional law: when the Constitution grants power and does not specify the means of exercising it, the recipient of that power generally may decide the means by which to exercise it. As noted earlier, this discretion is an implied feature of the power granted. An agent given power to do $\mathrm{X}$, without more, may choose the mechanism by which to exercise that power to do $\mathrm{X}$, consistent with the constraints, express and implied, the principal has placed on the agent.

Because the discretionary theory is a general principle of constitutional law, it applies to other powers. Consider something as simple as language. The Constitution never specifies the language to be used in laws and treaties. Whether Congress uses English or some other language in its bills is left to its discretion, for the Constitution never specifies the language to be used in bills and laws. Indeed, Congress might choose to pass bilingual bills, containing text in English and French. None of this should seem strange because the use of multiple languages has long been a staple of federal treaties, many of which are written in more than one language. ${ }^{193}$ The point is that while both laws and treaties must be in writing, the Constitution never specifies the language of those texts, leaving that decision to the institution empowered to craft the text.

Or consider the return of a vetoed bill. Whether the President returns a bill personally, via a messenger, or via e-mail to the originating chamber is for him to decide, because while the Constitution specifies "return" within ten days as a precondition to the exercise of the veto power, ${ }^{194}$ it never dictates the methods. ${ }^{195}$ In a related context regarding the signing of bills into law, the Office of Legal Counsel has opined that others may sign bills as agents for the President, meaning that the power to sign includes the option of signing the bill oneself or delegating that specific task to a subordinate. ${ }^{196}$

193 Early treaties were often in both English and another language. See, e.g., Treaty of Alliance, U.S.-Fr., Feb. 6, 1778, 8 Stat. 6 (French); Treaty of Amity and Commerce, U.S.Neth., Oct. 8, 1782, 8 Stat. 32 (Dutch); A Treaty of Amity and Commerce, U.S.-Prussia, July, Aug. \& Sept. 1785, 8 Stat. 84 (French); Treaty of Friendship, Limits, and Navigation, U.S.-Spain, Oct. 27, 1795, 8 Stat. 138 (Spanish).

194 U.S. Const. art. I, § 7, cl. 2.

195 The Office of Legal Counsel in the Department of Justice recently opined that the President could return bills electronically to Congress. See Opinion on Whether Bills May be Presented by Congress and Returned by the President by Electronic Means, $35 \mathrm{Op}$. O.L.C. 1 (2011), available at www.justice.gov/olc/2011/bills-electronic-means.pdf.

196 See Opinion on Whether the President May Sign a Bill by Directing That His Signature Be Affixed to It, 29 Op. O.L.C. 1 (2005), available at www.justice.gov/olc/2005/ opinion_07072005.pdf. 
This choice is the President's to make because the Constitution never specifies a precise mechanism of signing.

The same flexibility is implicit in the Treaty Clause. The President must seek the Senate's advice and consent prior to ratifying a treaty. To get that advice and consent, the President might appear in person, ready to field questions as they arise. Or he might messenger the treaty and direct his aides to respond to senatorial queries. ${ }^{197}$ Though practice for over 200 years decisively favors the latter option, the Constitution dictates neither one. Indeed, the first President personally went to the Senate for its advice on a number of treaty matters, ${ }^{198}$ a practice that lapsed not because it was unconstitutional or improper, but because Washington and certain members of the Senate found it less than ideal.

Finally, think of the judicial power. Because the Constitution does not dictate how courts will exercise their judicial power, the courts may decide whether and how to issue opinions that accompany judgments. For example, the courts may decide whether to issue oral or written opinions. ${ }^{199}$ Likewise, courts can decide whether there will be a majority opinion or merely seriatim opinions. $^{200}$ Courts may even decide that certain cases or matters do not need an opinion, meaning that they may exercise judicial power with a judgment unaccompanied by any explanatory opinion.

As hinted at above, some constitutional interpreters recognize that a constitutional grant of power implicitly comes with certain discretion in the manner the power will be exercised. The Office of Legal Counsel seems eager to recognize the discretion inherent in the verbs "present [ ]," "return," and "sign," all found in Article I, Section 7, probably because such flexibility empowers the President. ${ }^{201}$ It is right to find such flexibility.

But other times this discretion has been lost on the interpreter. It seems to have been lost on the Marshall Court not once, but twice. Besides Marbury, the discretion as to means implicit in grants of power was also lost to the Court in United States $v$. Wilson. As noted earlier, the Court decided that a pardon vests upon delivery because, the Court said, pardons are a species of deed, and deeds require delivery to be valid or effective. ${ }^{202}$ Hence, in Wilson Marshall established a single point in time when a pardon vested and thereby ruled out other means of pardoning. Yet what is to prevent a pardon from

197 See Joseph Hayden, The Senate and Treaties, 1789-1817, at 19-20 (1920) (discussing early Senate practices and rules that discussed these possibilities).

198 Id. at 20-22.

199 Until the 19th century, the Supreme Court did not issue written opinions, leaving Justices to give reasons for their opinions from the bench. See William D. Popkin, The Evolution OF THE Judicial Opinion 82-85 (2007).

200 Prior to the Marshall era, the Supreme Court typically used seriatim opinions following the English practice. See 2 George Lee Haskins \& Herbert A. Johnson, History of the Supreme Court of the United States 382-83 (1981).

201 See supra note 196 and accompanying text.

202 See United States v. Wilson, 32 U.S. (7 Pet.) 150, 161 (1833). 
vesting when the President signs it or at some other time of his choosing? ${ }^{203}$ More generally, what reason is there to suppose that pardons must even be written? The Constitution says nothing suggesting that a pardon must be reduced to writing, much less that it must be delivered. Indeed, Attorneys General have long endorsed the idea of an implied or constructive pardon. ${ }^{204}$

In 2008, the question of when a pardon vests resurfaced. Two days before Christmas, George W. Bush signed and sealed a "master warrant" that purported to pardon Isaac Robert Toussie, a convicted felon. ${ }^{205}$ Within a day, the President learnt that Toussie's father had contributed to the Republican Party. On Christmas Eve, Bush "revoked" the pardon. ${ }^{206}$

The Department of Justice apparently concluded that the pardon had not vested because no pardon had been delivered to Toussie. ${ }^{207}$ Some commentators, citing Wilson, agreed. ${ }^{208}$ Despite the sense that President Bush had "revoked" the pardon, there was no revocation as much as there was a decision not to complete the process of granting a pardon. After all, under Wilson, no pardon was final until delivery and acceptance. One commentator suggested that there had been a long practice of Presidents revoking completed pardons. ${ }^{209}$

Others disagreed, noting that President Bush had a signed a document that declared that the President "hereby grant[s] full and unconditional par-

203 Marshall seemed moved by the fact that a court could not take judicial notice of a private pardon unless it was brought to its attention. See id. While that may be true, it hardly matters for when the pardon vests. It surely does not show that delivery is necessary for the pardon to vest.

204 Opinions of the Attorneys General endorsed the concept of implicit or constructive pardons, relying upon English jurists. See Effect of a Promotion on a Suspended, Passed Midshipman, 4 Op. Атt'y Gen. 8, 9 (1852); Court Martial-Pardon, 6 Op. Aтt'y Gen. 123, 123 (1856). The general idea is that if an offender is ordered to do something inconsistent with his or her potential prosecution or conviction, etc., the official so ordering has pardoned the offender, albeit implicitly or constructively. Hence if the President ordered a federal warden to release an inmate who still had time left on his sentence, the order should be understood, at the very least, as a remission of that inmate's remaining sentence.

More generally, one might suppose that if the President publicly declares in a speech that he "hereby pardons" various offenders for their offenses, that would be a pardon. Again, nothing in the Constitution specifies that pardons must be reduced to writing.

205 See Jeffrey Crouch, The Toussie Pardon, "Unpardon," and the Abdication of Responsibility in Clemency Cases, 38 Congress \& Presidency 77, 85 (2011).

206 See David Stout \& Eric Lichtblau, Pardon Lasts Just One Day for Man in Fraud Case, N.Y. Times, Dec. 24, 2008, at A14.

207 See id. at A22.

208 See, e.g., George Lardner Jr., A Test of the Power to Unpardon, WAsh. Post, Jan. 14, 2009, at A17.

209 See P.S. Ruckman, Jr., Can a President Revoke a Pardon He Has Granted?, Pardon Power (Dec. 25, 2008), http://www.pardonpower.com/2008/12/can-president-revokepardon-he-has.html. 
dons to the following named persons," including Toussie. ${ }^{210}$ Furthermore, the Administration had called to convey news of the pardon. These commentators argued that the pardon had been delivered orally and had been accepted (by either Toussie or his attorney). ${ }^{211}$ For all these reasons, some believed that the pardon had vested and could not be revoked. Others noted that neither delivery nor acceptance was necessary, pointing out that Presidents previously had issued pardons benefitting the dead, a context where delivery and acceptance is generally impossible. ${ }^{212}$

Under the discretionary theory, Toussie's case was somewhat easy. The Constitution does not specify when a pardon vests, leaving it to the President to decide. President Bush could have made a pardon vest prior to delivery, with delivery, upon acceptance, or after certain conditions were satisfied (say a public apology and restitution). The language of the master warrant signaled that Bush unconditionally pardoned Toussie via the warrant itself because it stated that it constituted a pardon. That the Department of Justice never prepared or delivered an individualized pardon to Toussie was irrelevant. While Toussie might have preferred a pardon in this form, the master warrant was a wholly adequate pardon.

Does a constitutional actor have complete discretion as to the exercise of her constitutional powers? No. An agent given power to do X must comply with the constraints, express and implied, the principal has imposed on the agent. Because some limits are implied, a mere reading of the grant of power may convey an inaccurate sense of the agent's authority.

For instance, though the federal courts have judicial power to decide cases, they cannot decide cases by reference to which party is wealthier or has a more congenial political ideology. Those bases cannot be relevant in a system where justice is supposed to be blind to party attributes. Nor could a federal judge decree that a trial by combat would decide a case. By the late eighteenth century that method of resolving judicial disputes generally was forbidden to Anglo-American jurists.

Accordingly, any claim about the proper means of exercising some power must be based not only the Constitution's text but also on a contextually-sensitive understanding of the extant practices. Had the Constitution been enacted in the fourteenth century, perhaps Article III judges could decide cases by reference to who survived a trial by combat.

The text and history of the appointment power leads me to conclude that the President enjoys tremendous discretion in the manner and timing of appointment because there are very few express constraints and seemingly few implied constraints. With respect to the type of opinions that courts issue (majority vs. seriatim) and with respect to when pardons vest, I am similarly confident that the relevant actors had discretion.

210 Brian C. Kalt, Once Pardoned, Always Pardoned, WASH. Post, Jan. 26, 2009, at A11; see also Harlan J. Protass, Signed, Sealed, Delivered, but Not Yours, ChI. Triв., Jan. 23, 2009, at C29.

211 Kalt, supra note 210, at A11; Protass, supra note 210, at C29.

212 See Protass, supra note 210, at C29. 
In sum, when the Constitution grants powers without specifying the mechanisms for their exercise, the institution empowered generally may decide the means of implementing the power. This discretion extends to the form the exercise of power will take and when the power will be exercised. At the same time such discretion is subject to express and implied constraints, meaning that the institution does not necessarily have absolute discretion as to the means of that power's exercise.

\section{Restrictions on the Rule of Appointer Discretion}

As noted, sometimes the Constitution constrains the manner in which a power may be exercised. To present a bill to the President, the House and Senate must first pass a bill with the same text. ${ }^{213}$ To make a treaty, the President must first receive the Senate's consent. ${ }^{214}$ Courts must have a justiciable case or controversy prior to exercising the judicial power.

The general rule of appointer discretion is subject to its own set of constraints. First, while the Senate is in session, the President cannot appoint individuals to non-inferior offices unless he first secures Senate consent. ${ }^{215}$ For such offices, there is a required sequence because under the Appointments Clause, the Senate's consent is clearly an ex ante constraint on appointments ${ }^{216}$ and not an ex post means of ousting people from office.

Second, the President generally cannot appoint unless there is a preexisting office created by Congress. The Appointments Clause refers to offices "established by law,"217 a phrase that suggests that though the President appoints, only Congress may create the offices via laws. Indeed, that has been our practice from the Constitution's inception. The only exception to this rule is a curious one: the President has long created foreign diplomatic postings, such as the ambassador to France, without the assistance of Congress. $^{218}$ Even for such offices, the Senate must provide its advice and consent prior to appointment, at least while it is in session.

A third constraint on appointment discretion is implied. As suggested earlier, certain people cannot be appointed without their acceptance of the office. In particular, it seems clear that no member of Congress can be appointed to an executive or judicial office without her consent. The Incompatibility Clause signals that no attempted unilateral appointment of a sitting

\footnotetext{
213 U.S. Const. art. I, § 7, cl. 2.

214 U.S. Const. art. II, $§ 2$.

215 Id.

216 Recently Professor Matthew Stephenson has argued that Senate consent can be implied and need not be express. See generally Matthew C. Stephenson, Can the President Appoint Principal Executive Officers Without a Senate Confirmation Vote?, 122 Yale L.J. 940 (2013).
}

217 U.S. Const. art. II, § 2.

218 Saikrishna B. Prakash \& Michael D. Ramsey, The Executive Power over Foreign Affairs, 111 YALE L.J. 231, 309 (2001). 
member of Congress to an executive or judicial office can succeed. ${ }^{219}$ If a President could so appoint a legislator to a federal office, it would only be so because the presidential appointment automatically divested the legislator of her congressional post. But if an appointment could accomplish that, the President would have the power to oust any federal legislator by unilaterally appointing them during the Senate's recess. Surely the Constitution grants no such power to the President, via the Appointments Clause or otherwise. If the President wishes to appoint a Senator to serve as Secretary of State, the Senator must resign from the Senate prior to the appointment vesting. Of course a Senator would only resign if she desired the appointment in the first place, meaning that the President cannot appoint federal legislators to federal office without their express or implied acceptance of the office.

Perhaps the appointment of sitting judges to an executive office is subject to a similar constraint. If one supposes that a federal judge cannot simultaneously occupy an executive office based on a sense that there is an implied incompatibility bar that forbids appointment to multiple branches, ${ }^{220}$ then the President cannot force an executive appointment on a federal judge. For instance, a circuit court judge cannot be appointed to be a district attorney without her consent. Any attempt would fail because of the implied incompatibility rule and because the President clearly lacks the power to unilaterally oust a federal judge, even via an exercise of his appointment power. Because the President lacks the power to oust a federal judge, she can appoint a federal judge to an executive office only after the judge resigns from her judicial office (at least under the theory that there is an implied incompatibility bar). As noted, a resignation signals consent to the new appointment, making it clear that an appointment of a federal judge to an executive office only may occur via her acceptance of the new office.

In sum, the President lacks a power to unilaterally appoint any member of the House or Senate to an office of the United States. And it may be that the President cannot force an executive appointment on a federal judge. Either sort of appointment arguably requires consent to the new appointment, meaning that the President may not confer unwanted executive offices on federal legislators and federal judges.

Some might suppose that there is a fourth constraint on an appointer's discretion. In particular, one might imagine that the power to appoint only can be exercised in the present, meaning that the President cannot use the appointment power to dictate that an appointment will vest in the future. ${ }^{221}$ For instance, if the President wanted an appointment to vest on January 1, perhaps he must take action on January 1, rather than attempting to provide, in advance, that an appointment automatically will vest on the first of the

219 U.S. Const. art. I, § 6, cl. 2 (“[N]o Person holding any Office under the United States, shall be a Member of either House during his Continuance in Office.").

220 Typically the case for an implied prohibition on office holding across the judicial and executive departments rests on the supposedly longstanding practices of the branches. For discussions of this view, see Calabresi \& Larsen, supra note 188, at 1121-45.

221 My esteemed colleague, John Harrison, brought this possibility to my attention. 
year. Likewise, maybe the President cannot appoint conditional upon the occurrence of an event, such as the Senate's consent. Under this reading of the Appointments Clause, the power to "appoint" is the power to grant an office in the present; it does not encompass authority to dictate that an appointment will or may vest at some point in the future.

To flesh out the contours of these supposed restrictions, consider the Organic Act. ${ }^{222}$ It allowed the President to appoint as many justices of the peace as he thought necessary. Rather than acting only at the points in time when he deemed it necessary to appoint new justices of the peace, the President might want to decree that new appointments automatically vest if certain population thresholds are met. For instance, the President might provide, via executive order, that when a particular threshold had been exceeded, a named person would be a new justice of the peace. Yet if the appointing power is a power to vest an office only in the present, the President could not appoint someone to office over time. He would have to take action to appoint as and when he wished to fill an office.

Perhaps it makes sense to read the power to appoint as something that only may be exercised in the here and now and not over time. Reading the appointment power in this way has a salutary effect, because it prevents the current President from deciding personnel matters beyond his term. If the President could use his appointment power to appoint conditionally upon some event far into the future, a sitting President could extend his sway beyond his term in office. For instance, the President would be able to decide, with the Senate's consent, the next occupant of a Supreme Court seat currently occupied. Indeed, a President might even be able to decide the successor to the successor, in much the same way the Act of Settlement determined succession for the English Crown. ${ }^{223}$

Despite some reasons to read the appointment power narrowly, the better view is that the President can use that power to decide that appointments will vest in the future. To begin with, there are other powers of government that clearly have effect in the future, suggesting that there would be nothing untoward with understanding the appointment power as permitting conditional appointments. When Congress exercises its lawmaking powers, it creates laws, some of which only take effect in the future, typically upon a certain date. Hence the legislative power encompasses the ability to make rules that do not take effect immediately.

The President has similar powers. Using the pardon power, the President can issue conditional pardons that only take effect if individuals take particular actions, such as admitting guilt, laying down arms, paying a fine, etc. $^{224}$ This means that the pardon power includes authority to extend forgiveness in the future, upon the satisfaction of conditions.

222 Act of Feb. 27, 1801, ch. 12, 2 Stat. 103 (1801).

223 Act of Settlement, 1701, 12 \& 13 W. \& M. 3, c. 2 (Eng.).

224 See generally Harold J. Krent, Conditioning the President's Conditional Pardon Power, 89 CAL. L. Rev. 1665 (2001) (discussing the benefits of allowing the President to make pardons conditional on future conduct or events). 
Consider the ratification of treaties. Under the Constitution, the President can make treaties, provided the Senate consents. ${ }^{225}$ According to the terms of typical treaties, a treaty is made once the parties ratify it. Suppose the United States has, via the President, ratified a treaty before the other party or parties have ratified it. Subsequently, the other parties ratify it. Must the President ratify again in order to exercise his power to make treaties? In other words, is the power to make treaties a power to make treaties in the here and now and not a power to make treaties conditional on another nation's ratification? If the treaty power were read as only the power to make treaties in the here and now, the President could only ratify a treaty previously ratified by the other party or parties. This has never been our practice. The treaty power has been read for two hundred years as including the power to make treaties conditioned upon the subsequent ratification of the treaty by other nations. Presidents have often ratified first, with the treaty automatically going into effect if the other party ratifies. ${ }^{226}$ In such cases, no further presidential action is necessary.

Finally, consider conditional nominations. One of the best sources of candidates for office is the pool of existing officers. A lieutenant may be made a captain and a captain a major. An assistant deputy Treasury Secretary may be made a deputy Secretary, and a deputy Treasury Secretary. Presidents could choose to nominate each person in the chain separately, waiting for an actual promotion to make room for another vacancy. So the President might nominate a captain to be a major and only nominate a new captain after the previous captain vacates his former office.

Alternatively, the President could nominate to the captain and major offices, with the nomination to the captain's office conditional on the current captain's promotion to major. This is exactly the tack that George Washington took. The first President sometimes simultaneously nominated A for office X and B for office Y, where A currently occupied office Y. ${ }^{227}$ Although Washington's nomination of B to office $\mathrm{Y}$ was conditional, it was a nomination nonetheless. He never had to re-nominate $\mathrm{B}$ once office $\mathrm{X}$ actually became vacant due to the actual promotion of $\mathrm{A}$.

The appointment power, like the pardon, treaty, and nomination powers, is best read to include the ability to make appointments conditional upon some event. Hence, the President may decide that an appointment vests with the Senate's consent, upon some date certain, or when an office currently occupied becomes vacant. When the President makes a condi-

225 U.S. Const. art. II, § 2, cl. 2.

226 See Treaty of Amity, Commerce, and Navigation (Jay Treaty), U.S.-Gr. Brit., Nov. 19, 1794, 8 Stat. 116 (discussing wherein President ratified and England ratified only later).

2272 The Documentary History of the First Federal Congress of the United States of America 99 (Linda Grant de Pauw et al. eds., 1974) (nominating John Sitgreaves to be a Judge and William Hill to be an Attorney "in place of John Sitgreaves, if his nomination as Judge meets your concurrence"); $i d$. at 131 (confirming Ziegler, Doyle, and Sedam, with Doyle succeeding Ziegler and Sedam succeeding Doyle, thereby indicating that Washington conditionally nominated Doyle and Sedam). 
tional appointment, he exercises his appointment power over time, with the appointment actually vesting when the conditions are met.

But even if Presidents can only appoint in the present and cannot make conditional appointments, perhaps Presidents could work around this restriction by issuing standing orders to appoint. In other words, even if the appointment power, by itself, is not up to the task, maybe that power coupled with the President's authority to direct the executive branch is sufficient. If the President declares on January 1 that an appointment will vest on March 1 and that he should be deemed to have made the appointment on that date in the future, he need not restate his desire to appoint an individual in order for the appointment to vest. On March 1, his subordinates can take whatever measures are useful or necessary, including issuing the commission and allowing the individual to assume office, on the understanding that the appointment has vested pursuant the President's standing order.

This system of standing orders to appoint may seem odd to some. Yet Presidents certainly exercise other powers via standing orders having effects in the present and in the future. Consider military orders. The President could issue an order only good for one event, much like a ticket that is only good for the day sold. Or he can issue standing orders that have effect in the future. Either way, he is acting as Commander in Chief. Likewise, as Chief Executive of his branch, the President can create standing rules for the conduct of executive officers without having to reissue them every day. The executive orders related to cost-benefit analysis are of this sort, creating durable rules that executive officers must follow until they are countermanded. ${ }^{228}$ If the President can issue standing orders that his subordinates, civil and military, must obey, those standing orders can pertain to the steps that officers must take to ensure that an appointment shall vest upon some event or occurrence in the future.

There remains the concern that a President might appoint to office well after he leaves office, thereby extending his powers beyond his term. This should not long trouble us. Presidents routinely take actions that have effects beyond their terms in office, such as issuing pardons, appointing individuals who remain in office after the President's term, and issuing standing directives to executive officers via executive orders. In the case of executive orders, they continue in force unless the new executive rescinds or modifies them. Their continuing force causes no alarm precisely because the new Chief Executive may modify them at will.

As long as an appointment has not vested, the successor President may alter or eliminate the conditional appointment. So while an incumbent might try to make a series of appointments that will vest after he leaves the Presidency, the successor President always may nullify the conditional

228 See, e.g., Exec. Order No. 13563, 76 Fed. Reg. 3821 (Jan. 18, 2011); Exec. Order No. 12,886, 58 Fed. Reg. 51,735 (Sept. 30, 1993). 
appointments, in the same way that a sitting President may nullify or modify an executive order issued by a predecessor. ${ }^{229}$

In sum, the better view is that the President can decide that an appointment will vest in the future. Whether the appointment power is exercised via a conditional appointment or by a standing appointment order is of no consequence. If the President can do either, he can make appointments vest immediately upon the Senate's consent, on a date certain, upon acceptance, or when the current occupant vacates the office.

\section{The Functions of Commissions}

The Constitution obliges the President to commission officers. ${ }^{230}$ In Marbury, Marshall claimed that transmission of the commission to the appointee was not required by the Constitution or by law. ${ }^{231}$ If the Commissions Clause never requires delivery of a commission to an appointee, it does no more than establish a record-keeping requirement, one satisfied by a ledger with a list of appointees.

The Great Chief Justice was certainly mistaken, likely blinded by a desire to insist that delivery to the appointee was irrelevant. To begin with, early federal commissions were addressed to people outside the executive branch. Some were addressed to the individual appointed, ${ }^{232}$ making it odd to suppose that the addressee never had a right to something directed to him. Most were addressed to the world. ${ }^{233}$ They typically began with the President's name and title and then said, "To all who shall see these Presents, Greeting." 234 After this introduction came the specification of the office and

229 For example, President Obama's first Executive Order rescinded President George W. Bush's Executive Order, which had given former presidents robust authority to claim executive privilege. Exec. Order No. 13,489, 74 Fed. Reg. 4669 (Jan. 21, 2009).

I do not believe that the President may exercise his appointment power to prevent a successor from nullifying or modifying his conditional appointments, just as I do not believe that a President may issue a non-rescindable executive order. As long as the appointment is not made, the President may arrest and terminate the pending appointment. Cf. Krent, supra note 224, at 1704 (claiming that Presidents cannot bind their successors).

230 U.S. Const. art. II, $\$ 3$ (explaining that the President "shall Commission all the Officers of the United States").

231 Marbury v. Madison, 5 U.S. (1 Cranch) 137, 160 (1803) ("The transmission of a commission [to the appointee], is a practice directed by convenience, but not by law.").

232 See Washington's Commission from Congress (June 19, 1775), in ThIs Glorious Struggle 6 (Edward G. Lengel ed., 2007) ("To George Washington, Esquire[:] We reposing especial trust and confidence in your patriotism, conduct and fidelity Do by these presents constitute and appoint to be General and Commander in Chief of the army.").

For an earlier example of such a commission, see Commission to William Lewis, in 5 The Papers of Thomas Jefferson, supra note 18, at 58.

233 See Appointment of David Rittenhouse (Mar. 14, 1791), available at https://www. gilderlehrman.org/collections/81d7fd7b-9e7a-46ba-8491-410736174915; see also commissions on file with author (commissions of William Nelson, Oliver Wolcott, John Brooks).

234 See Appointment of David Rittenhouse, supra note 233; see also commissions on file with author, supra note 233. 
individual. The commissions typically closed with, "In Testimony whereof I [the President] have caused these Letters to be made Patent and the seal of the United States to be hereunto affixed." ${ }^{335}$ Again, it seems strange to address a commission to the world, to speak of the President's "[t]estimony", and to make the letters "patent," 236 if there was no duty to deliver the commission to an officer who might produce it whenever his authority was in doubt. A commission that does no more than gather dust alongside other commissions in the State Department files hardly testifies to anything.

Little wonder that many spoke of commissions as evidence of an appointment. As Secretary of State, Jefferson had said that commissions were "public evidence" of an appointment. ${ }^{237}$ President John Adams doubted that commissions were the "exclusive evidence of appointments," 238 thereby confirming that they were a species of evidence. Some of his advisors said the same, with one Secretary claiming, "it is desirable that in all cases where officers enter upon duty, they should have it in their power by producing their Commissions to show that clearest and best evidence of authority."239 Written evidence of an appointment is always better than oral testimony. Something signed and sealed was likewise better than informal papers or letters.

Whereas today, officers keep their commissions as mementoes of their service, some were asked to return theirs ${ }^{240}$ and others returned them voluntarily. $^{241}$ George Washington requested that John Marshall send back his commission after the latter declined to serve as a district attorney. ${ }^{242}$ Presumably returns were necessary to ensure that no one believed that the appointed individual remained in office after a declination or resignation.

235 See Appointment of David Rittenhouse, supra note 233.

236 "Letters patent" were government documents open to the world, meant to be a matter of public record, and usually addressed to mankind. They were in contradistinction to "letters close" which were for the "closed up and sealed" and for a particular person. See Richard Burn, A New Law Dictionary 433 (1792).

237 Thomas Jefferson, Opinion on the Powers of the Senate Respecting Diplomatic Appointments, supra note 22, at 378-79.

238 Letter from John Adams to J. McHenry, supra note 174, at 666.

239 Letter from Benjamin Stoddert, Secretary of the Navy, to James McHenry, supra note 118.

240 See Letter from Tobias Lear to Matthew Clarkson (March 29, 1792), in 10 THE Papers of George Washington, supra note 135, at 164.

241 See Letter from Alexander Hamilton to George Washington (July 20, 1793), in 13 The Papers of George Washington 255 (Theodore J. Crackel ed., 2007) (noting return of commission); see also Letter from Robert Denny to George Washington (Dec. 6, 1793), in $14 \mathrm{id}$. at 478 (voluntarily returning commission). The Editors of the Thomas Jefferson Papers believe that most military officers did not return their commissions at the close of the Revolutionary War. See George Washington's Resignation as Commander-in-Chief, Editorial Note, 6 The Papers of Thomas Jefferson, supra note 18, at 403, 408. Whether that practice of officers keeping their commissions continued under the Constitution is unknown.

242 See Letter from George Washington to John Marshall (Nov. 23, 1789), in 4 THE PAPERS Of George Washington, supra note 171, at 192, 193 n.2 (asking for return of commission because "some other person must be appointed"). 
Other times, the return was symbolic, meant to show respect to the appointer. George Washington's famous resignation as Commander in Chief occurred via his public return of his commission to Congress. In a ceremony fraught with symbolism, Washington ended his emotional 1782 farewell address to Congress by declaring that he was returning his commission, whereupon he pulled it out from his bosom and handed it to the President of the Continental Congress. ${ }^{243}$

When we think of a commission serving as evidence of an appointment, the modern equivalent might be the badge used by police officers. The badge reveals that someone is a law enforcement officer, whether they wear a uniform or not. And the return of the badge similarly signals that the officer has resigned or been ousted from office.

Commissions also might serve as the means of an appointment. ${ }^{244} \mathrm{~A}$ commission might declare that it does "hereby appoint" the named individuals to a particular office ${ }^{245}$ or that the appointer "do[es] constitute" 246 some person an officer. In such cases, the commission had a dual role, serving not only as evidence of an appointment, but also an instrument of appointment.

Sometimes commissions were used to establish the metes and bounds of the office, in much the same way that a deed for land might describe the parcel conveyed. The English Crown typically issued rather detailed commissions to its colonial governors, documents that authorized, constrained, and obliged in various ways. ${ }^{247}$ Such commissions, containing numerous sections and running for pages, were longer than many statutes.

Similarly, when the Continental Congress appointed George Washington as Commander in Chief, his commission served as a means of conveying power and issuing rudimentary instructions. It gave Washington "full power and authority to act as [he] shall think for the good and Welfare of the service." 248 It further required all soldiers to obey Washington and enjoined him to exercise the soldiers and maintain strict discipline. ${ }^{249}$

Because Congress creates offices via its laws, commissions under the Constitution typically do little more than mention the office conveyed. That

243 See George Washington's Resignation as Commander-in-Chief, supra note 241, at 402-08.

244 See Thomas Sheridan, A General Dictionary of the English Language (1780) (defining commission as " $\mathrm{t}]$ he act of entrusting any thing; a trust, a warrant by which any trust is held; a warrant by which a military officer is constituted"). Sheridan defined "to commission" as "[t]o empower, to appoint." Id. Although commissioning could be used as a synonym for appointing, that clearly was not the only usage, as evidenced by early American practices.

245 George Washington, Commission, supra note 146, at 258-259 (appointing Thomas Johnson, Daniel Carroll, and David Stuart).

246 Commission as Lieutenant Colonel (Oct. 25, 1780), in 26 The Papers of Alexander Hamilton, supra note 114, at 401 (appointing Alexander Hamilton).

247 See Evarts Boutell Greene, The Provincial Governor in the English Colonies of North America, at app. A (1898) (reprinting detailed commissions for several colonial governors).

248 See Washington's Commission from Congress, supra note 232, at 6.

$249 I d$. 
is to say, because the President lacks constitutional authority to create offices, he has no occasion to specify the features of an office in the commissions he issues. But one can imagine scenarios where the President might use a commission to limit discretion or issue general instructions to an executive officer. For instance, the President might use a commission to direct a cabinet Secretary to take particular considerations into account in promulgating new regulations. Indeed, commissions might be a rather useful means of giving particularized instructions to a specific officer.

Finally, commissions also might be issued prior to appointment, effectively constituting an offer for office. The Jefferson administration concluded that the circuit court commission sent to District Judge Benjamin Bourne was not evidence of an appointment. Rather, it was an implicit offer of an office that Bourne belatedly accepted weeks later. ${ }^{250}$ More generally, the President might send a commission and explicitly declare that the office vested only when the individual accepted it. Such a sequence would effectively subvert the "natural order" that Secretary of State Jefferson discerned in the Constitution. ${ }^{251}$

In sum, commissions can serve many roles. Typically, they serve as evidence of an appointment. But they may serve other functions as well, including a means of appointing, a method of delimiting an office, or as an offer of appointment. The precise functions a commission play turns upon the context and its content.

\section{E. Congress, the Senate, and the Vesting of Appointments}

Because appointers have discretion as to when their appointments vest and because the Constitution permits multiple appointers, there is the potential for uncertainty as to when someone became an officer. To ameliorate such confusion, appointers should establish bright lines for when their appointments vest. A clear, simple rule, set out in advance, has much to commend it. Hence, the President might declare via an executive order that none of his appointments are complete without the delivery of a commission. Other appointers might borrow the best practices of others, avoiding the need to reinvent the wheel. For instance, rather than coming up with its own rules, a court of law might wish to borrow whatever appointing rules the President implements.

Of course federal appointers might choose to promulgate no such rules, leading to confusion about when its appointments vest. Faced with uncertainty about when offices vest, Congress might wish to enact a statute dictating a specific process. Congress might declare that appointments only vest with the signing of a commission. Or Congress might specify that appointments vest upon publication in the Federal Register.

250 See supra text accompanying note 189.

251 Thomas Jefferson, Opinion on the Powers of the Senate Respecting Diplomatic Appointments, supra note 22, at 378-79. 
The difficult question is whether Congress may dictate when appointments vest. Congress enjoys the power to enact necessary and proper laws for carrying into execution the powers of the federal government, including the appointment power. ${ }^{252}$ Some might suppose that the Necessary and Proper Clause includes authority to specify how and when appointment powers will be carried into execution.

Yet there are sound reasons for doubting that Congress has power to tell the other branches how to exercise their powers, even when such congressional regulation might be beneficial. ${ }^{253}$ The Necessary and Proper Clause clearly enables Congress to help implement presidential and judicial powers, say by creating institutions that help the President and courts better exercise their respective powers. But the Clause, properly understood, does not empower Congress to direct how other branches exercise their respective powers. If it did, Congress might forbid presidential pardons for murderers and specify the content of the First Amendment to the courts. It seems rather unlikely that the Sweeping Clause sweeps so far. And if it does not permit such laws, the Clause likewise should not be read to authorize statutory rules for when an appointment vests.

Even if this reading of the Necessary and Proper Clause is mistakeni.e., one concludes that Congress may specify how and when an appointment vests-that conclusion would not detract from the claim that the Constitution itself cedes discretion to appointers about how and when to make appointments. One might well suppose that while the Constitution adopts a default rule of appointer discretion, Congress nevertheless may dictate, via legislation, the methods and timing of appointments. ${ }^{254}$

Given its check on appointments, there is the separate and interesting question of whether the Senate (acting alone) may decide when an appoint-

252 See U.S. Const. art. I, § 8, cl. 18.

253 See Saikrishna Prakash, Regulating Presidential Powers, 91 Cornell L. Rev. 215 (2005) (reviewing Harold J. Krent, Presidential Powers (2005)) (arguing that Congress lacks a generic power to regulate exercise of presidential powers).

254 The Court has yet to say whether Congress can either prescribe the means of appointment or establish conditions precedent to an appointment. In Le Baron, the Court held that Congress could require that an individual take certain actions "before he shall enter on the possession of the office." United States v. Le Baron, 60 U.S. (19 How.) 73, 78 (1856). But Le Baron also declared that the appointment was complete after the commission was signed and sealed. $I d$. The two statements can be squared if one supposes that one can be appointed to office without necessarily being able to function in it. In other words, the Court might have supposed that while the President appoints, Congress can prevent appointees from functioning in office.

An early twentieth-century case, Glavey $v$. United States, suggested that the appointment might not be complete until a required oath was taken, thereby hinting that the President could not unilaterally appoint at least as to such offices. 182 U.S. 595, 604 (1901) (declaring that an appointment was "complete, at least, when [an individual] took the required oath and transmitted evidence of that fact to the Secretary"). 
ment will vest. ${ }^{255}$ Although the Senate has apparently never tried to dictate when an appointment will vest, the Senate's advice and consent resolution might be a vehicle for constraining when an appointment vests.

There is precedent for advice and consent resolutions constraining executive power. Occasionally the Senate consents to the making of a treaty only if certain changes are made. Such conditional consent does not permit the President to ratify the treaty without the changes demanded by the Senate, because the Senate has not consented to the original treaty.

Given that the Senate may advise the President to alter a treaty he has negotiated, even in significant ways, one might suppose that the Senate likewise could advise when an appointment will vest. The Senate might declare that it "advises and consents to the appointment of [a nominee] on April 1." Or the Senate might advise and consent to an "appointment to be made via commission." If the Senate has such power, it might have as much discretion as the President in deciding when an appointment vests.

I do not endorse the notion that the Senate can impose such constraints on the President via its advice and consent resolution. Indeed, there are important differences between conditional consent in the treaty context and the sort of conditional consent discussed above. In the treaty context, the conditional consent goes to the substance of the treaty and not, to my knowledge, to the timing and method of the President's ratification. In the appointment hypothetical discussed above, the conditional consent affects the timing and method of the appointment. These differences may lead some to reject the idea that the Senate may set constraints on the conferral of offices.

Moreover, it is important to note that while any such advice and consent resolutions could constrain the President's power to appoint, they would not compel anything. As noted, the President does not have to appoint someone merely because the Senate consented to the appointment. If the President did not like the procedural constraints placed on his appointment power, he could decide not to appoint the person at all. ${ }^{256}$

In any event, regardless of whether the Constitution permits the Senate to constrain when or how an appointment vests, such senatorial power does not detract from the main thrust of the discretionary theory. The principal claim here is that the President has discretion to decide the timing and means of his appointments. That claim's validity does not turn on whether the Senate may, through its Advice and Consent role, impose conditions on how the President exercises his discretion.

255 Of course, the Senate influences when an appointment will vest, because until the Senate consents to an appointment, the President cannot appoint (at least while the Senate is in session).

256 In most cases, such a tack would seem akin to throwing out the baby with the bathwater. If the ultimate goal is appointing someone to office and not to mount a defense of the discretion that the Constitution implicitly confers upon appointers, the President likely will swallow and accept whatever minor constraints the Senate might impose. 


\section{F. Reconsidering the Theories of Appointment}

Even as the Constitution does not enshrine the automatic appointment theory, neither does it bar the President from declaring that an appointment vests upon the Senate's consent. The President might wish people to assume their offices immediately without the need for him to take any appointive action subsequent to the Senate's consent. The downside of such a default rule is that Senate debate might generate new information about the nominee, facts that might lead the President to abort the appointment. The risk of damaging revelations is not so high if the Senate confirms and the person occupies an office from which the President can remove at pleasure; in that case the President can simply remove his misbegotten appointee. But in the case of federal judges, the President might wish to refrain from having appointments automatically vest upon Senate concurrence. Alternatively, with a high enough confirmation threshold, the President might decide, rather sensibly, that there is no reason to revisit the nominee's fitness for office. For instance, a President might provide that a judgeship automatically vests when the Senate consents to it with a certain supermajority, say eighty percent. Absent that threshold, he will decide whether to appoint after the Senate consents.

Similarly, though the Constitution does not dictate that appointments vest upon either commission delivery or office acceptance, nothing prevents the President from conditioning the appointment on such events. The best reason for conditioning appointment on commission delivery is if the President wants someone to refrain from taking official action until she has physical proof of appointment. Yet in modern times, those who doubt an appointee's authority have ample means of verifying an appointment. Besides the internet, there are books that list officers. ${ }^{257}$ While commissions remain evidence of an appointment, they certainly are not the only means of judging whether someone is a federal officer.

Likewise, the President has no need to make appointments vest with acceptance. For some individuals, such as federal legislators (and perhaps federal judges), the Constitution itself requires something like acceptance prior to the grant of an office. For others, the President almost always will gauge willingness to serve well in advance of appointing. This was not always possible in eras with slower means of communicating.

Even though conditioning an appointment on commission delivery or office acceptance likely confers little benefit in the modern age, other conditional appointments might be somewhat useful. With the Senate's advice and consent, the President might create conditional backup appointments that would automatically vest should the current occupant leave office via removal, resignation, or death. Having backup appointments would not save time; it would merely shift the use of time forward. But it would help ensure

257 See, e.g., Committee on Oversight and Government Reform, 112th Congress, The Plum Book (2012); Leadership Directories, The Federal Yellow Book (2012). 
a quick transition (and avoid disruption and delay) once an office became vacant. ${ }^{258}$

What of the claim that appointment must occur via commissioning? That a commission can be a means of appointing hardly means that the Constitution establishes commissioning as the sole means. As we have seen, Presidents often appointed prior to signing any commission, ${ }^{259}$ probably because they were eager for appointees to assume office.

Finally, the claim that appointment must be a wholly separate act from Senate consent and presidential commissioning reads too much into the Constitution. Admittedly, Presidents occasionally acted in a manner consistent with this theory. Yet it is also clear from early practice that the President need not separate appointment from these other acts.

In sum, constitutional text, structure, and early practice do not establish a single constitutionally required means of appointing. To the contrary, they suggest that the Constitution grants the appointer considerable flexibility. Presidents appointed by various means not because they acted upon mistaken readings of the Constitution. Rather, Presidents appointed in different ways because the Constitution granted them discretion regarding how and when they made appointments.

\section{The Marbury Appointment Revisited}

What does the discretionary theory suggest about William Marbury? Was he appointed on March 3, 1801, or is there some reason to suppose that John Adams never appointed Marbury, as Jefferson later claimed?

The arguments developed here suggest that the plaintiffs ought to have deposed their patron, John Adams, and obtained his testimony about when he vested the appointment. Of course, Adams would have said that the appointment vested before Jefferson took office, without any need for delivery of commissions. One exceedingly important piece of evidence to corroborate any such claim would be William Marbury's commission, signed by Adams, and signed and sealed by John Marshall. If we had the commission, we could read it and see what Adams purported to do. If in the commission Adams had claimed to have already appointed Marbury-"I have appointed you to the office of the Justice of the Peace"-the commission likely would be conclusive evidence of a prior appointment. If the commission purported to appoint- "I hereby appoint you"-it would have served as the instrument of appointment. If the commission provided that the appointment would vest upon delivery- "when you receive this, you are appointed"-that information would settle the matter in favor of the delivery argument, at least with respect to these appointments.

258 Congress has ameliorated some of these difficulties by allowing existing officers to serve in an "acting" capacity until a new officer is properly appointed. See, e.g., 5 U.S.C. $\$ 3345$ (2012) (permitting other officers to assume the duties of a vacant office for a period of time).

259 See supra Section II.B. 
Unfortunately, we lack William Marbury's commission or a copy of it. It, along with the other undelivered commissions, likely was destroyed. ${ }^{260}$ Because we lack the best evidence, we can never be certain whether John Adams appointed William Marbury on March 3.

Yet we do have a strong sense of what Marbury's commission likely said. That evidence makes it almost certain that Adams had appointed William Marbury. Appendix A reproduces a March 3, 1801 commission for George Gilpin, one of the midnight justices of the peace. ${ }^{261}$ The commission signed by John Adams and sealed by John Marshall provided that "I have nominated and by and with the advice and consent of the Senate do appoint him a Justice of the Peace for the Count of Alexandria in the District of Columbia." Given the language used ("I . . . do appoint"), Adams appointed Gilpin on March 3rd.

Adams signed more than forty justice of the peace commissions on that day. A template likely was used, ${ }^{262}$ meaning that the commissions would have been identical, save for the appointee's name and the county of the District of Columbia. Hence it is quite likely that Marbury's commission mirrored Gilpin's. That is to say, Adams likely signed a commission for Marbury that purported to "appoint" on March 3, 1801.

When one considers the situation, it is hard to reach any other conclusion. March 3 was the last day of the Adams Presidency. Adams clearly was trying to foist officers on the new President and to reward Federalists. Undoubtedly, Adams would have attempted to complete the appointments on his last day. The language of the Gilpin commission indicates that Adams believed he had appointed Gilpin, Marbury, and the other justices of the peace. Given Adams's early experience with the commission-less officers on the court martial, the outgoing President knew that he did not need to sign, seal, or send anything to make an appointment. Why would he make lastminute appointments that required the assistance of others when he could make them unilaterally? Adams was never called to the stand in Marbury; had he been summoned, he might have recalled the Hunt court martial episode and told the Court that he had appointed the justices of the peace before signing or even seeing the commissions, meaning that they were but evidence of appointments already made.

Had Marbury actually received his commission, he would have had the best evidence of his appointment. Instead he had to gather testimony of the clerks in the Department of State and get them to admit that they had seen a signed and sealed commission for him. But as Marshall indicated in his opinion and as Marbury's lawyer claimed, Marbury did not need the commission

260 See Letter from a Member of Congress, supra note 43; Letter from Thomas Jefferson to Abigail Adams, supra note 44, at 271.

261 See infra app. A.

262 It was common to create a template with blanks and then send to the printer who would then print multiple copies. See Contingent Expenses of the Department of State, 1790-1793, in 17 The Papers of Thomas Jefferson, supra note 18, at 359, 361, 365-66, 369, 374 (listing expenses for various blank commissions bought in bulk). 
to function. ${ }^{263}$ Adams had appointed Marbury, whether or not the latter had a commission to prove it.

Oddly enough, Marbury's commission would not have helped him assume office. Recall that in 1801, Jefferson never claimed that the appointments were not made. Rather, he said that he would treat them as nullitiesas if they were never made-because they were "indecent," having been made after the defeat of John Adams. As noted earlier, his actions are best understood as an implicit removal of those justices of the peace. The most the delivery of Marbury's commission might have accomplished is that Jefferson might have recess-appointed Marbury, as he did for other midnight appointees who received their commissions.

Of course, by the time they filed suit, neither Marbury nor his fellow plaintiffs had any thought of assuming office. They had waited a year to press their claim and apparently had never tried to assume office, the definition of sleeping on their rights. Moreover, their attorney suggested that his clients were uninterested in office. They were fighting for the "principle," said Charles Lee. ${ }^{264}$ Knowing this made it easier for Marshall to declare that Jefferson had violated the Constitution and a statute, for the Court was all but assured that the plaintiffs would do nothing with the Court's opinion other than relish its expected criticisms of Jefferson and Madison.

Though the Court concluded that the petitioners had a right to their commissions, its ruling had no effect on Jefferson. He ignored the Supreme Court's dicta on when an appointment vests in much the same way he had ignored the appointments of John Adams. Both were treated as if they were nullities.

\section{Conclusion}

John Marshall's opinion in Marbury canvassed several (though not all) possible appointment methods, each of which was, and is, plausible. Their plausibility should have raised the possibility that each was a suitable means of vesting offices and that there was no constitutionally prescribed means of appointing. Instead, Marshall struggled to find a single right answer that the Constitution never supplies.

The discretionary theory makes sense of previous practice and Marshall's failure to disprove any of the theories he mooted. The Constitution provides that the President may appoint to office after certain conditions are satisfied, such as the Senate's advice and consent. But it does not specify when or how the appointment must be made. When the Constitution grants a power but does not specify the means of its exercise, the grantee may decide the means of its exercise. The best reading of the Constitution is that because it never specifies when or how an office vests, it conveys discretion to the President to determine those modalities.

263 Marbury v. Madison, 5 U.S. (1 Cranch) 137, 150-51 (1803).

$264 I d$. 


\section{Appendix A}

John Adams, President of the United States of America

To all who shall see these Presents-Greeting:

Know Ye, That reposing especial trust and confidence in the integrity, ability, diligence, and discretion of George Gilpin, Esquire, I have nominated and by and with the advice and consent of the Senate do appoint him a Justice of the Peace for the County of Alexandria, in the District of Columbia, and do authorize and empower him to execute and fulfil the duties of that office according to law; and to have and to hold the said office with all the powers, privileges, and emoluments to the same of right appertaining unto him the said George Gilpin for the term of five years from the day of the date hereof.

In Testimony whereof I have caused these Letters to be Patent and the seal of the United States to be hereunto affixed. Given under my hand at the City of Washington the third day of March in the year of our Lord one thousand eight hundred and one, and of the Independence of the United States of America the twenty fifth.

John Adams (signature)

By the President

John Marshall (signature)

Acting as Secretary of State 
